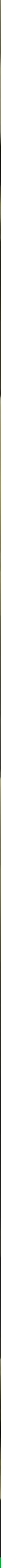

\title{
Manual for PEARLNEQ v6
}



Manual for PEARLNEQ v6 
This Technical report was produced in accordance with the Quality Management System of the Statutory Research Tasks Unit for Nature \& the Environment, part of Wageningen University \& Research.

The mission of the Statutory Research Tasks Unit for Nature and the Environment (WOT Natuur \& Milieu) is to carry out statutory research tasks on issues relating to nature and the environment. These tasks are implemented in order to support the Dutch Minister of Agriculture, Nature and Food Quality, who is responsible for these issues. We provide data about agri-environment, biodiversity and soil information to compile reports as part of national and international obligations, and we work on products of the PBL Netherlands Environmental Assessment Agency, such as the Assessment of the Human Environment reports.

\section{Disclaimer WOt-publicaties}

The 'WOt-technical reports' series presents the findings of research projects implemented for the Statutory Research Tasks Unit for Nature \& the Environment by various centres of expertise.

WOt-technical report 200 presents the findings of research funded by the Dutch Ministry of Agriculture, Nature and Food Quality (LNV). 


\section{Manual for PEARLNEQ v6}

J.J.T.I. Boesten ${ }^{1}$, M.M.S. ter Horst ${ }^{1}$

1 Wageningen Environmental Research

BAPS project number WOT-04-008-024

Statutory Research Tasks Unit for Nature \& the Environment

Wageningen, October 2021

wOt-technical report 200

ISSN 2352-2739

DOI $10.18174 / 544295$ 


\section{Abstract}

J.J.T.I. Boesten, M.M.S. ter Horst (2021). Manual for PEARLNEQ v6. Wageningen, The Statutory Research Tasks Unit for Nature and the Environment (WOT Natuur \& Milieu), WOt-technical report 200. 52 p.; 3 Figs; 0 Tabs; 12 Refs; 4 Annexes.

Aged sorption is a process by which a plant protection product can become more strongly adsorbed to soil over time, resulting in, among other things, reduced leaching to groundwater. The inclusion of aged sorption is part of a higher tier in the groundwater leaching assessment in the EU registration procedure for plant protection products. Data of experimental studies that demonstrate an increase in sorption over time can be used to derive model-input parameters for assessments using the FOCUS Groundwater scenarios. This report describes the use of the new version of PEARLNEQ, version 6, that can be used to estimate aged sorption parameters for the active ingredient of the plant protection product on the basis of a soil incubation experiment with this substance. The new version can calculate (optionally) the $95 \%$ confidence intervals of the fitted parameters by bootstrapping which are probably more accurate than the intervals provided by PEST.

Keywords: aged sorption, pesticide, inverse modelling, PEARLNEQ, non-equilibrium sorption, PEST, soil, leaching, plant protection product, PEARL

\section{Referaat}

J.J.T.I. Boesten, M.M.S. ter Horst (2021). Manual for PEARLNEQ v6. Wettelijke Onderzoekstaken Natuur \& Milieu, WOt-technical report 200. 52 blz.; 3 fig.; 0 tab.; 12 ref; 3 Bijlagen.

Niet-evenwichtssorptie is een proces waardoor naar verloop van tijd een gewasbeschermingsmiddel sterker gebonden wordt aan bodemdeeltjes, hetgeen onder andere kan leiden tot minder uitspoeling naar het grondwater. Het meenemen van niet-evenwichtssorptie is een onderdeel van een hogere tier van de beoordeling van de uitspoeling naar het grondwater in de EU toelatingsprocedure. Gegevens van experimentele studies die de toename van de sorptie in de tijd aantonen kunnen gebruikt worden om de invoergegevens van modellen af te leiden voor berekeningen met de FOCUS Grondwaterscenario's. Dit rapport beschrijft het gebruik van de nieuwe versie van PEARLNEQ, versie 6, die gebruikt kan worden om een schatting te maken van de niet-evenwichtssorptie parameters van de actieve stof van het gewasbeschermingsmiddel op basis van een incubatie-experiment met grond waaraan deze stof is toegevoegd, De nieuwe versie kan ook desgewenst de $95 \%$ betrouwbaarheidsintervallen berekenen van de gefitte parameters door middel van bootstrapping, die waarschijnlijk nauwkeuriger zijn dan de intervallen berekend door PEST.

Trefwoorden: lange-termijn sorptie, bestrijdingsmiddel, inverse modellering, PEARLNEQ, nietevenwichtssorptie, PEST, bodem, uitspoeling, gewasbeschermingsmiddel, PEARL

\section{(C) 2021 Wageningen Environmental Research}

PO Box 47, 6700 AA Wageningen

Phone: +31317474700; e-mail: mechteld.terhorst@wur.nll

The Statutory Research Tasks Unit for Nature and the Environment (WOT Natuur \& Milieu; an unit under the auspices of the Stichting Wageningen Research), PO Box 47, NL 6700 AA Wageningen, T +31 3174854 71, info.wnm@wur.nl, www.wur.nl/wotnatuurenmilieu. WOT Natuur \& Milieu is part of Wageningen University \& Research.

This report can be downloaded free of charge from https://doi.org/10.18174/544295 or from www.wur.nl/wotnatuurenmilieu. WOT Natuur \& Milieu provides no printed copies of reports.

- Acquisition, duplication and transmission of this publication is permitted with clear acknowledgement of the source.

- Acquisition, duplication and transmission is not permitted for commercial purposes and/or monetary gain.

- Acquisition, duplication and transmission is not permitted of any parts of this publication for which the copyrights clearly rest with other parties and/or are reserved.

WOT Natuur \& Milieu assumes no liability for any losses resulting from the use of the research results or recommendations in this report. 


\section{Preface}

EFSA has developed guidance on how aged sorption studies for pesticides should be conducted, analysed and used in regulatory assessments. The Standing Committee on Plants, Animals, Food and Feed agreed that this guidance will be applicable as of 1 April 2021 (date of dossier submission) to dossiers submitted under Regulation (EC) No 1107/2009.

PEARLNEQ is one of the tools that can be used to analyse such studies. This manual has been prepared to support the user of version 6 of PEARLNEQ.

In this new version of PEARLNEQ, a methodology has been implemented to estimate more accurately the $95 \%$ confidence interval of the fitted parameters. In addition, several modifications have been implemented to increase the precision of the input for the PEST model or to improve the applicability of the model. 



\section{Contents}

$\begin{array}{lr}\text { Preface } & \mathbf{5}\end{array}$

$\begin{array}{lr}\text { Summary } & 9\end{array}$

$\begin{array}{lr}\text { Samenvatting } & 11\end{array}$

$\begin{array}{llr}1 & \text { Introduction } & 13\end{array}$

$2 \quad$ Precautionary remark $r$

3 Description of the incubation experiment $\quad 17$

$4 \quad$ Theoretical background $r$

$\begin{array}{llr}5 & \text { Fitting procedure for parameters with PEST } & 23\end{array}$

$\begin{array}{llr}6 & \text { Installation of PEARLNEQ } & 25\end{array}$

$\begin{array}{llr}7 & \text { Running the example } & 27\end{array}$

8 Run PEARLNEQ with your own data $r$

9 Assessment of confidence intervals of parameters by bootstrapping 33

$\begin{array}{lr}\text { Literature } & \mathbf{3 7}\end{array}$

$\begin{array}{lr}\text { Justification } & 39\end{array}$

$\begin{array}{llr}\text { Annex } 1 & \text { Example input file }\end{array}$

$\begin{array}{lll}\text { Annex } 2 & \text { Results of the default example } & 43\end{array}$

Annex $3 \quad$ Comparison between an analytical solution and PEARLNEQ 46

Annex $4 \quad$ Example calculations of bootstrapping confidence intervals 4 



\section{Summary}

This manual describes the PEARLNEQ v6 software package. This package can estimate long-term sorption parameters using results of aged sorption studies with soil using a sub-model for sorption and transformation that is identical to the sub-model used for that purpose in FOCUS_PEARL.

The sub-model assumes two types of sorption sites: equilibrium sites and non-equilibrium sites. The sorption isotherms for both sites are described with Freundlich equations. The content sorbed at the equilibrium site is assumed to be continuously at equilibrium, and the content sorbed at the nonequilibrium site is described with a pseudo first-order sorption rate equation. The software package offers two options for describing the transformation rate in soil. The first option is that the transformation rate in soil is proportional to the amount in the liquid phase plus the amount sorbed at the equilibrium site. The second option is that the transformation rate in soil is proportional to the amount in the liquid phase. So, for both options, the content sorbed the non-equilibrium site is not subject to transformation.

The mathematical equations describing the sub-model are solved via a Fortran program. An additional Fortran program generates the necessary input files for the PEST optimisation package. Instructions are given for how to obtain optimised parameters using an example dataset and, subsequently, instructions are given how to obtain parameters using your own data.

The PEST optimisation package also provides estimates of confidence intervals of the parameters. However, these may be inaccurate. Therefore, a procedure is provided to estimate more accurately the $95 \%$ confidence intervals by bootstrapping. A disadvantage is that this requires much more computation time. 



\section{Samenvatting}

Deze handleiding beschrijft het PEARLNEQ v6 softwarepakket. Dit pakket kan de nietevenwichtssorptie parameters schatten door gebruik te maken van niet-evenwicht sorptie ('aged sorption') studies met een sub-model voor sorptie en omzetting dat identiek is aan het sub-model voor dat doel in FOCUSPEARL.

Het sub-model gaat uit van twee soorten sorptieplekken, evenwichtssorptieplekken en nietevenwichtssorptieplekken. De sorptie-isothermen voor beide plekken worden beschreven met de Freundlich vergelijkingen. Het gehalte gesorbeerd op de evenwichtssorptieplek is continu in evenwicht en het gehalte gesorbeerd op de niet-evenwichtssorptieplek wordt beschreven met een pseudo eersteorde sorptie snelheidsvergelijking. Het softwarepakket biedt twee opties voor het beschrijven van de omzettingssnelheid in de grond. De eerste optie is dat de omzettingssnelheid recht evenredig is met de hoeveelheid van de stof in de vloeibare fase van de bodem vermeerderd met de hoeveelheid die gesorbeerd is op de evenwichtssorptieplek. De tweede optie is dat de omzettingssnelheid recht evenredig is met de hoeveelheid in de vloeibare fase. In beide opties is de hoeveelheid die gesorbeerd is op de niet-evenwichtssorptieplek niet beschikbaar voor omzetting.

De wiskundige vergelijkingen van het sub-model worden opgelost via een Fortran programma. Een aanvullend programma genereert de benodigde invoerbestanden van het PEST optimalisatiepakket. Instructies worden gegeven op welke manier geoptimaliseerde parameters verkregen kunnen worden met behulp van een voorbeeld dataset en hierop aansluitend worden instructies gegeven hoe de parameters verkregen kunnen worden met eigen gegevens.

Het PEST optimalisatie pakket levert ook schattingen van het betrouwbaarheidsinterval van de parameters. Echter, deze kunnen onnauwkeurig zijn. Daarom is een procedure uitgewerkt om het 95\% betrouwbaarheidsinterval meer nauwkeuriger te kunnen schatten door middel van bootstrapping. Een nadeel van deze methode is wel dat er veel meer rekentijd voor nodig is. 



\section{Introduction}

This document describes a PEARLNEQ-PEST combination which can be used to estimate the parameters for long-term sorption kinetics in the PEARL model on the basis of an incubation experiment for a certain soil and a certain pesticide. The combination also provides the transformation half-life at reference temperature (when long-term sorption kinetics are included in PEARL, the definition of this half-life changes so it has to be recalculated; see Boesten and van der Linden, 2001). If the incubation experiment has been carried out at multiple temperatures, the molar enthalpy of transformation for the transformation rate in soil can be optimised simultaneously.

The differences with the previous release (PEARLNEQ v5) are as follows:

- When the option 'equal' is used for weighing residuals, PEARLNEQ calculates weighing factors to ensure that the two types of measurements (i.e. the remaining mass in the system and the concentration in the liquid phase) obtain an approximately equal weight in the fitting procedure.

- The weight factors are written with more decimals to the PEST input file; in previous versions, only three decimals were written (e.g. 0.020 instead of 0.0204 ) which may result in the option 'inverse' rounding errors in the order of percents.

- The lower limit of the initial mass in the system has been set to $0.001 \mathrm{mg}$ (previously $0.1 \mathrm{mg}$ ).

- Additionally, a procedure is provided to estimate more accurately the confidence intervals of the parameters using bootstrapping.

- A small bug was repaired in the calculation procedure of the system variables at the last sampling time (in the previous version the values of the system variables at this last sampling time were those from one timestep before the last sampling time; this happened only if the calculation stopped at the last sampling time, so no error occurred if the calculation proceeded somewhat longer; as the timestep is typically in the order of $0.01 \mathrm{~d}$, the error made was small).

Recently, the European Commission provided guidance on aged sorption (EC, 2021) indicating that PEARLNEQ is one of the recommended tools that may be used to obtain aged sorption parameters. However, note that PEARLNEQ contains additional features that may not be in line with this guidance (e.g. the option to estimate the Arrhenius activation energy described at p. 23 of the guidance, or the option to obtain confidence intervals by bootstrapping, as described in Chapter 9). 



\section{Precautionary remark}

This PEARLNEQ-PEST software tool should be seen as an introduction to fitting results of experiments on long-term sorption kinetics to the sorption sub-model used in the PEARL model. The tool shows you how PEST can be coupled to a Fortran program that contains this PEARL sorption sub-model (i.e. PEARLNEQ.EXE) but it should not be seen as a ready-to-use tool. The tool provides you with example input files for the PEST optimisation package and shows you how to organise this optimisation. We had to make a number of assumptions for generating these PEST input files (e.g. upper and lower bounds of parameters, weighing factors for each measurement, etc.). We do not claim that these assumptions are defensible for your problem; they are our best guesses, but they may not be appropriate for your problem. It is your responsibility to check the appropriateness of the result obtained. We do not accept any responsibility for use of PEARLNEQ. 



\section{Description of the incubation experiment}

The PEARLNEQ-PEST tool can be used to fit the results of the following experiment. A number of jars is filled with soil. Each jar contains the same mass of moist soil. At the start of the experiment, the same initial mass of pesticide is added to the moist soil in all jars. The jars are incubated at a fixed temperature (or at a few temperatures). At certain points in time, the remaining total amount of pesticide is measured via an extraction with organic solvent. At the same time, the concentration in the liquid phase of the moist soil is measured. The liquid phase can be collected by centrifuging the moist soil over a filter. As an alternative for centrifuging, a desorption experiment can be carried out by adding a certain volume of aqueous solution (e.g. $\mathrm{CaCl}_{2}$ solution) and subsequent shaking for about $24 \mathrm{~h}$.

It may also be useful to have additional results of measurements of an adsorption isotherm with an equilibration time of about $24 \mathrm{~h}$ using the same soil and pesticide. 



\section{$4 \quad$ Theoretical background}

PEARLNEQ assumes a Freundlich two-site sorption sub-model: one site for equilibrium sorption and a second site for long-term sorption kinetics. The operational definition for the equilibrium sorption sites is that they have reached equilibrium after about $24 \mathrm{~h}$ shaking of a well-stirred suspension of the soil in water. The long-term sorption sites do not reach equilibrium within $24 \mathrm{~h}$. PEARLNEQ assumes firstorder degradation kinetics; it offers two options for describing the degradation kinetics. The first option is that the degradation rate is proportional to the number of molecules present in liquid phase and those sorbed to the equilibrium site. The second option is that the degradation rate is proportional to only the number of molecules present in liquid phase (see Beltman et al., 2008). However, molecules sorbed on the non-equilibrium site are assumed not to degrade in both options. This conceptual model is presented in Figure 1. The sub-model for sorption and degradation kinetics used in PEARLNEQ can be described as follows (Leistra et al., 2001):

$$
\begin{aligned}
& M_{p}=V c_{L}+M_{S}\left(X_{E Q}+X_{N E}\right) \\
& X_{E Q}=K_{F, E Q} c_{L, R}\left(\frac{c_{L}}{c_{L, R}}\right)^{N} \\
& \frac{d X_{N E}}{d t}=k_{d}\left(K_{F, N E} c_{L, R}\left(\frac{c_{L}}{c_{L, R}}\right)^{N}-X_{N E}\right) \\
& K_{F, N E}=f_{N E} K_{F, E Q} \\
& \frac{d M_{p}}{d t}=-k_{t}\left(V c_{L}+M_{s} X_{E Q}\right) \\
& \frac{d M_{p}}{d t}=-k_{t} V c_{L}
\end{aligned}
$$

$$
K_{F, E Q}=m_{O M} K_{O M, E Q}
$$

where:

$M_{p}=$ total mass of pesticide in each jar $(\mu \mathrm{g})$, acronym Mas

$V=$ the volume of liquid in the soil incubated in each jar $(\mathrm{mL})$, acronym VolLiq

$M_{S}=$ the mass of dry soil incubated in each jar $(\mathrm{g})$, acronym MasSol

$C_{L}=$ concentration in the liquid phase $(\mu \mathrm{g} / \mathrm{mL})$, acronym ConLiq

$C_{L, R}=$ reference concentration in the liquid phase $(\mu \mathrm{g} / \mathrm{mL})$, acronym ConLiqRef

$X_{E Q}=$ content sorbed at equilibrium sites $(\mu \mathrm{g} / \mathrm{g})$

$X_{N E}=$ content sorbed at non-equilibrium sites $(\mu \mathrm{g} / \mathrm{g})$

$K_{F, E Q}=$ equilibrium Freundlich sorption coefficient $(\mathrm{mL} / \mathrm{g})$, acronym CofFreEql

$K_{F, N E}=$ non-equilibrium Freundlich sorption coefficient $(\mathrm{mL} / \mathrm{g})$, acronym CofFreNeq

$N=$ Freundlich exponent (-), acronym ExpFre

$k_{d}=$ desorption rate coefficient $\left(\mathrm{d}^{-1}\right)$, acronym CofRatDes

$f_{N E}=\mathrm{a}$ factor for describing the ratio between the equilibrium and non-equilibrium Freundlich coefficients (-), acronym FacSorNeqEql 
$k_{t}=$ degradation rate coefficient $\left(\mathrm{d}^{-1}\right)$

$m_{O M}=$ mass fraction of organic matter in the soil $(\mathrm{kg} / \mathrm{kg})$, acronym CntOm

$K_{O M, E Q}=$ coefficient of equilibrium sorption on organic matter $(\mathrm{mL} / \mathrm{g})$, acronym KomEql

PEARLNEQ does not use the transformation rate coefficient $\left(k_{t}\right)$ as input parameter, but the half-life at reference temperature (acronym DT50Ref, DegT50). They are related as follows (assuming first-order kinetics):

$\operatorname{DegT50}=\ln (2) / k_{t}$

The effect of soil temperature on the transformation rate coefficient in soil is described by the Arrhenius equation:

$$
f_{T}=\exp \left(\frac{-E}{R}\left[\frac{1}{T}-\frac{1}{T_{R E F}}\right]\right)
$$

where

$f_{T}=$ the multiplication factor for the rate coefficient (-)

$E=$ molar enthalpy of transformation $(\mathrm{kJ} / \mathrm{mol})$, acronym MolEntTra

$T=$ temperature of the soil during the incubation (K)

$T_{R E F}=$ the reference temperature for the specified DegT50 (K)

$R=$ the gas constant $\left(\mathrm{kJ} \mathrm{mol}^{-1} \mathrm{~K}^{-1}\right)$.

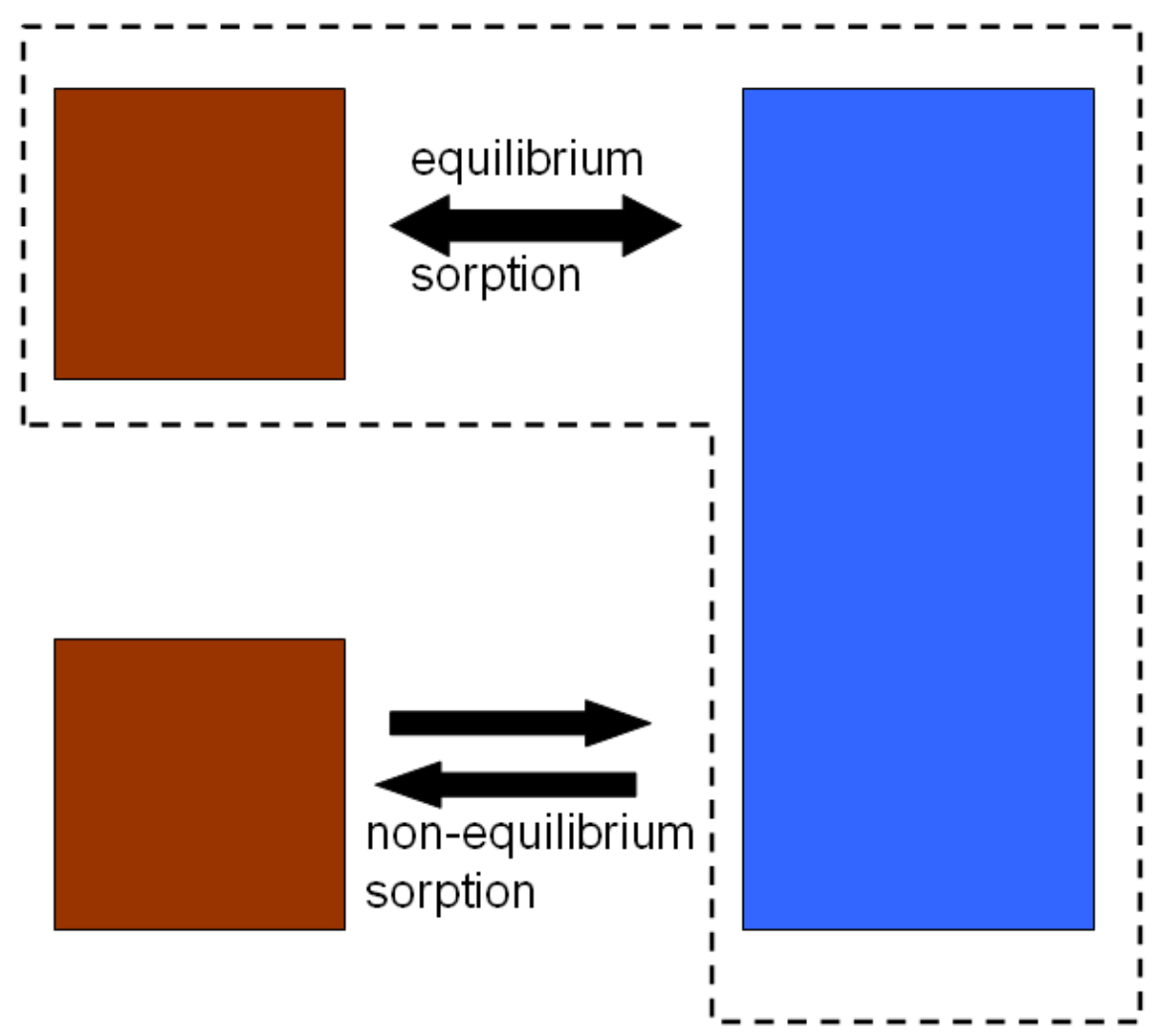

\section{subject to transformation}

Figure 1 Conceptual representation of the PEARLNEQ model. Note that there are two options for the transformation process as described by Eqns 5-A and 5-B. Only the option described by Eqn 5-A is shown here.

Often, no concentration measurements in the soil pore water are available, but instead, at each sampling point in time, a certain volume of water (usually a $\mathrm{CaCl}_{2}$ solution) is added to soil and the suspension is shaken for about $24 \mathrm{~h}$, after which the concentration in the supernatant is measured. In 
such a case, the fit has to be based on these concentration measurements in the supernatant of the soil-water suspension.

This is simulated in PEARLNEQ as follows:

A) it is assumed that full equilibrium is reached for the equilibrium sorption site during the desorption experiment (i.e., shaking for $24 \mathrm{~h}$ ).

B) it is assumed that desorption from the non-equilibrium sorption site can be ignored during the desorption experiment.

Assumption $A$ is justifiable because this is precisely the operational definition of the equilibrium sorption site. Assumption $B$ is justifiable because desorption coefficients for long-term kinetics are usually in the order of $0.01 \mathrm{~d}^{-1}$, which implies that amounts desorbed within 1 day are negligibly small.

Using these assumptions, the concentration in the liquid phase of the supernatant after desorption can be estimated by stating that (i) the total content of substance in the moist soil and the soil-water suspension have to be equal, and (ii) the content sorbed at the non-equilibrium sites in the moist soil and in the soil-water suspension are equal. Using Equation 1 then results in the following equation:

$$
V c_{L, M S}+M_{S}\left(X_{E Q, M S}+X_{N E}\right)=\left(V+V_{A D D}\right) c_{L, S U S}+M_{S}\left(X_{E Q, S U S}+X_{N E}\right)
$$

where:

the subscript MS indicates the moist-soil system

the subscript SUS indicates the soil-water suspension system and

$V_{A D D}=$ volume of liquid (usually $\mathrm{CaCl}_{2}$ solution) added to the soil at each sampling point just before starting the $24 \mathrm{~h}$ desorption experiment $(\mathrm{mL})$, acronym VolLiqAdd.

At each sampling point in time, Equation 9 can be rewritten (using Eqn 2) into an equation that contains only one unknown variable, i.e. the concentration in the liquid phase of the soil suspension $\left(c_{L, S U S}\right)$. PEARLNEQ always provides as output the concentration in the soil-water suspension as a function of time. If $V_{A D D}=0$, then this implies that the concentration in the moist soil is given.

PEARLNEQ provides as output also the so-called apparent sorption coefficient $\left(K_{D, A P P}\right)$. This is used for studies in which a certain volume of water (usually a $\mathrm{CaCl}_{2}$ solution) is added to soil and the suspension is shaken for about $24 \mathrm{~h}$. It is then defined as the total content sorbed at the end of the shaking period divided by $c_{L, \text { SUS }}$. This is calculated by PEARLNEQ as:

$$
K_{D, A P P}=\frac{X_{E Q, S U S}+X_{N E}}{c_{L, S U S}}
$$

PEARLNEQ solves the set of Eqn 1 to Eqn 9 numerically using Euler's method for integration of the state variables $M_{p}$ and $X_{N E}$. The time step for integration, $\Delta t$, is calculated as:

$$
\Delta t=\frac{A}{\max \left(k_{t} f_{T}, k_{d}\right)}
$$

where $A$ is an accuracy parameter (-) which was set to 0.003. Van den Berg et al. (2016) have shown that such a value of $A$ should give accurate results.

The concentration in the liquid phase is calculated via an iteration procedure as described in Appendix 4 of FOCUS (2006). Appendix 3 shows a test of the PEARLNEQ results against an analytical solution for the case of a linear isotherm $(N=1)$, indicating good correspondence between numerical and analytical results. 



\section{$5 \quad$ Fitting procedure for parameters with PEST}

The provided package assumes that the following variables need to be optimised:

- The initial mass of the pesticide (MasIni)

- The ratio between the equilibrium and non-equilibrium Freundlich coefficients (FacSorNeqEql)

- The desorption rate coefficient (CofRatDes)

- The half-life at reference temperature (DT50Ref) for the selected transformation option (Eqn 5-A or Eqn 5-B)

- The coefficient of equilibrium sorption on organic matter (KomEql)

- The molar enthalpy of transformation (MolEntTra); this can only be optimised if the experiment has been carried out at multiple temperatures.

It is assumed that all other variables are known.

The provided package assumes that the measurements that are fitted and consist for each point in time of:

- A mass of pesticide in $\mu \mathrm{g}$

- A concentration of pesticide in liquid phase in $\mu \mathrm{g} / \mathrm{mL}$.

PEST needs a number of input parameters for the fitting procedure (e.g. initial guesses of the fitting parameters, upper and lower bounds of parameters, criteria for the convergence of the iteration procedure, weighing factor for each measurement, etc.). The package provides values for all these input parameters, and we do not claim that these are the best choice for your dataset. Our experience is that the weighing factor for each measurement is the most important input parameter. Therefore, we offer two options for weighing:

1. 'equal', which gives an equal weight factor to all masses and an equal weight factor to all concentrations in the liquid phase

2. 'inverse', which gives a weight factor that is proportional to the inverse of the observed value (if the observed value is zero, the weight factor is set to 1.0)

The PEST optimisation is based on the sum of squares of differences between measured and fitted values with the understanding that each difference is multiplied with its weight factor. So, the weight of a measurement in the fitting procedure is determined by its contribution to this sum of squares. The option 'equal' implies that differences for high observed values get more weight (i.e. contribute more to the sum of squares) than differences for low observed values. As described above, the fitting procedure considers two quantities: mass of pesticide and the concentration in the liquid phase. Giving them the same weight factor may lead to the situation that the estimation of the parameters is dominated by one of the two. For example, if the mass is initially $50 \mu \mathrm{g}$ and the concentration in the liquid phase is in the order of $1 \mu \mathrm{g} / \mathrm{mL}$, then the fitting procedure would be dominated by the decline of the mass of pesticide. This would be inefficient use of the data. Therefore, in case of the option 'equal', all masses are given a weight factor of 1.0, and all concentrations in the liquid phase are given a weight factor equal to the average of all measured masses divided by the average of all measured concentrations. So, e.g., if the average of all masses would be 25 and the average of all concentrations 0.5 , then the concentrations will be given a weight factor of 50 , thus ensuring approximately equal weight of the two quantities in the optimisation procedure.

The option 'inverse' implies that each measurement gets more or less equal weight for the parameter estimation. This option ensures that, for example, an $5 \%$ difference between an observed and a fitted value obtains the same weight (i.e. contributes equally to the sum of squares) irrespective whether the value is high or low. This then is consistent with the concept of relative errors. The alternative option 'equal' gives all differences between observed and fitted values the same weight factor, which is consistent with the concept of absolute errors. This 'inverse' option gave the best results in a few tests and is considered the normal procedure for aged sorption studies, according to EFSA (2018, p.16). Measured masses and concentrations will usually be many orders of magnitude higher than 
their detection limits, so there is a priori no reason why the relative error of low values should be higher than that of high values. In principle, the user can check whether the differences between fitted and measured values are more consistent with the concept of relative errors than with the concept of absolute errors and use this check to decide between 'inverse' or 'equal' options.

Other important input are the initial guesses of the fitting parameters. While using PEARLNEQ, we noticed that the results regularly depend on these initial guesses. We therefore advise you to always perform a number of runs with different initial guesses.

The provided package can handle multiple observations for each point in time. The user can specify up to nine replicate sets. A replicate set can contain measurements at different time points and different temperatures. There is no restriction in the number of measurements in a replicate set. The different replicate sets do not necessarily need to contain the same number of measurements or the same time points of measuring. However, there is a restriction with respect to the temperatures. The user needs to specify in a separate table at which temperature the measurements are performed, and each replicate set should contain at least one measurement performed at each of the temperatures specified in the list.

We advise you to analyse the results carefully, especially the $95 \%$ confidence intervals of your parameters (Chapter 7 describes where you can find these). If the interval is wide for a certain parameter, this indicates that the estimated variable is very uncertain. As a consequence, it may be not meaningful to use it any further in the risk assessment; an alternative option would be to give it less weight in the subsequent averaging of parameter values. 


\section{Installation of PEARLNEQ}

PEARLNEQ is distributed in a zip file. Unzip the file and specify a path (e.g. c: \pearlneq). Be sure there is no space within the specified path, because this will cause failure. We suggest installing and running PEARLNEQ on your hard disk and a 64-bit system (running on a network disc or a 32-bit system may result in failure).

The package contains five directories: Neq_Bin, PEST, Neq_Fortran_source_files, Neq_Example and Bootstrapping.

- The Neq_Bin directory contains the PEARLNEQ executables, PEARLNEQ.EXE and PEARLMK.EXE. The PEST optimisation software is available in the PEST directory. As PEST is available freeware (http://www.pesthomepage.org), we included relevant executables of the latest version (version 17.1). Separate installation of PEST is not necessary.

- The Neq_Fortran_source_files directory contains the Fortran source files used to generate the PEST input files and the program that calculates the sorption kinetics.

- The Neq_Example directory contains results from an example study: bentazone in a Dutch sandy soil: the Vredepeel dataset (Boesten and Van der Pas, 2000).

- The Bootstrapping directory contains executables and batch files to assess the confidence interval of the parameters for long-term sorption kinetics in a more sophisticated way. 



\section{$7 \quad$ Running the example}

The following steps must be followed.

1. Run the example to check if everything works and get experience with the system. Go to the Neq_Example directory, and run the example, example.bat.

- The batch file will first call PEARLMK. This pre-processing program needs the example.mkn file as input and generates the input files for PEST, i.e. example.pst, example.tpl and example.ins (see Figure 2, RunId = 'example'). The 'pst' file is the PEST control file. The 'tpl'-file provides the template for the input file for PEARLNEQ and the 'ins'-file describes the location of the simulated values in the 'out'-file. Please note that in case of replicate datasets (in the example there are two replicates), there is an 'ins'-file for every replicate (example1.ins, example2.ins, etc).

- Next PEST programs PESTCHEK, TEMPCHEK and INCHEK are executed to check respectively the 'pst' file, the 'tpl'-file and the 'ins'-file(s). Press 'enter' after each check to proceed.

- Then, optimisation starts. PEST calls PEARLNEQ several times (see Figure 2; in the example 39 times).

- If you get an error message after the first step (PEARLMK), type 'control-break' to stop the process and check the error messages available in the example.err file.

2. After successful optimisation, read the results from the file example.rec. The file can be opened with a text editor, e.g. Notepad. The relevant results, including parameter values, $95 \%$ confidence intervals and correlation matrices, can be found at the end of this file (Section OPTIMISATION

RESULTS, see Appendix 2). The meaning of the short acronyms in this rec-file is as follows:

fsne $=$ FacSorNeqEql

crd $=$ CofRatDes

$\mathrm{dt50}=$ DT50Ref

masini $=$ MasIni

komeql $=\mathrm{KomEql}$

met $=$ MolEntTra.

PEST also generates parameter sensitivity files etc. Details can be found in the PEST manual (Doherty, 2005).

3. PEARLNEQ will create an output file (example.out) and a log file (example.log). The output files are self-explanatory. The output file contains the result of the last run which is in PEST by definition the run with the optimised parameters.

4. The results from the output file (example.out) are the source for the best fit and can be used to create graphs. 


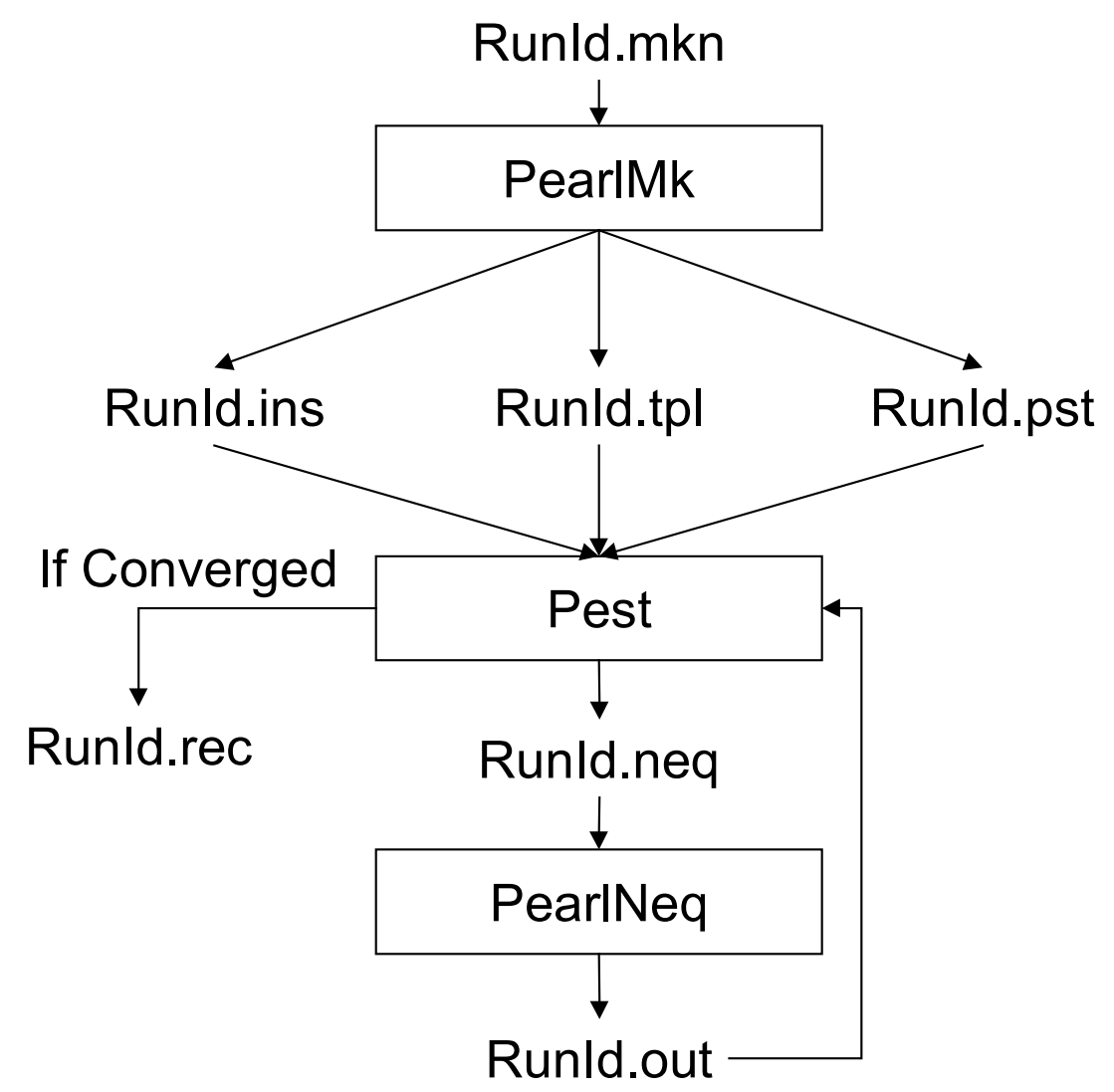

Figure 2 Dataflow diagram for the PEARLNEQ-PEST Combination. The acronym RunId is 'example' for the example provided. Note that in this example, there are two ins-files (example1 and example2) because the example contains two replicates. 
1. We assume that you have carried out an appropriate incubation experiment as described before. The first step of optimising your own data consists of editing the file example.mkn, which can be found in the example subdirectory of the PEARLNEQ directory. Open the file with a text editor e.g. Notepad. Please make a copy of this file and the.bat file before editing. Make sure there is no space in the new name. This will give an error. An example of this input file is listed in Appendix 1. The following parameters must be provided:

- TimEnd (d): The duration of the incubation experiment. This determines the length of the simulation period.

- MasIni $(\mu \mathrm{g})$ : The initial total mass of pesticide in each jar. In contrast to initial versions of PEARLNEQ, this parameter will be optimised. There is no default value for this parameter because it depends on the setup of the experiment.

- MasSol ( $\mathrm{g}$ ): The mass of dry soil incubated in each jar.

- VolLiqSol $(\mathrm{mL})$ : Volume of liquid in the moist soil in each jar during incubation.

- VolLiqAdd ( $\mathrm{mL}$ ): Volume of liquid added to the soil after incubation (i.e. the amount of liquid added to perform a conventional desorption equilibrium experiment).

- CntOm $\left(\mathrm{kg} \mathrm{kg}^{-1}\right)$ : Mass fraction of organic matter in the soil.

- ConLiqRef ( $\mu \mathrm{g} \mathrm{mL}^{-1}$ ): Reference concentration in the liquid phase.

- ExpFre (-): Freundlich exponent; use value taken from adsorption isotherm measured for this pesticide-soil combination.

- KomEqImL g ${ }^{-1}$ ): coefficient of equilibrium sorption on organic matter. This parameter will be optimised. We suggest to use as initial guess a value taken from adsorption isotherm measured for this pesticide-soil combination; in case you have no organic matter content of the soil, set the organic matter to 1.0 and specify the measured Freundlich equilibrium coefficient (see Eqn $6)$.

- FacSorNeqEql (-): factor describing the ratio $f_{N E}=K_{F, N E} / K_{F, E Q}$ as defined by Eqn 4. This parameter will be optimised, but you have to specify an initial guess here. We suggest a value of 0.5. As results may depend on initial guesses, we advise you to always perform a number of runs with different initial guesses.

- CofRatDes $\left(\mathrm{d}^{-1}\right)$ : the desorption rate coefficient. This parameter will be optimised, but you have to specify an initial guess here. We suggest a value of $0.02 \mathrm{~d}^{-1}$. As results may depend on initial guesses we advise you to always perform a number of runs with different initial guesses.

- OptSor option: sorption option to be used: 'Neql' for fits including long-term sorption kinetics (standard option) and 'Eql' for fits considering only equilibrium sorption.

- DT50Ref (d): the transformation half-life under reference conditions, applying to the equilibrium domain for the option of Eqn 5-A and to the liquid phase for the option of Eqn 5-B. This parameter will be optimised, but you have to specify an initial guess here. This initial guess could be the 'classical' half-life, which applies to the total soil system (i.e. the equilibrium domain + the non-equilibrium domain).

- TemRefTra (C): The reference temperature, for which the half-life will be provided (set to incubation temperature if data for only one temperature are available and set to $20^{\circ} \mathrm{C}$ if you have data for multiple temperatures).

- MolEntTra $\left(\mathrm{kJ} \mathrm{mol}^{-1}\right)$ : the molar enthalpy of transformation. This parameter will be optimised if you have carried out the experiment at multiple temperatures; otherwise it is a model-input. In any case, you have to specify a value (e.g. $60 \mathrm{~kJ} \mathrm{~mol}^{-1}$ ) which will be used as an initial guess in case of data for more than one temperature.

- Tem (C) table: List of temperatures at which the incubation experiment has been carried out. One temperature is OK if only data for one temperature are available.

- NumRepSet (-): Number of replicate sets.

- Opt weights option: options for weights. Two options for weighing are offered: 'equal' which gives an equal weight to all pesticide masses and an equal (but different) weight to all concentrations (see Chapter 5 for details) and 'inverse' which gives a weight that is proportional 
to the inverse of the observed value; if the observed value is zero, the weight is set equal to 1.0 in any case; you can inspect the weights in the 'pst' file.

- Opt transformation option: option for the concept of the degradation rate. The two options are 'EqIDom' (transformation in the equilibrium domain as described by Eqn 5-A) and 'LiqPhs' (transformation in the liquid phase only as described by Eqn 5-B).

- Observations table: List of observations. Column 1 contains the time (d), the Column 2 the temperature, Column 3 contains the total mass of pesticide in the system $(\mu \mathrm{g})$ and Column 4 contains the concentration of pesticide $\left(\mu \mathrm{g} \mathrm{mL}^{-1}\right)$ measured in the pore water of moist soil (then VolLiqAdd $=0$ ) or in the water phase after a desorption experiment (in which case VolLiqAdd is not zero). Column 5 contains the number (integer) of the replicate set, and Column 6 contains the characters 'OBS'. You can specify up to nine replicate sets. A replicate set can contain measurements at different time points and different temperatures. There is no restriction in the number of measurements in a replicate set. The different replicate sets do not necessarily need to contain the same number of measurements or the same time points of measuring. However, each replicate set should contain at least one measurement performed at each of the temperatures specified in the Temperature table. Measurements in the Observations table should be sorted: firstly by column 5 (number of replicate set; integer); secondly by Column 2 (temperature); and thirdly by Column 1 (time). Specify missing values or values you do not want to include in the optimisation procedure (e.g. outliers) as -99.999 .

2. Modify the contents of the example.bat file (with right mouse button, select edit): replace 'example' everywhere by the name of the copied input file. Repeat step 1-5 of Chapter 7. Note that in the example two replicate sets are used. Each replicate set is linked to an PEST instruction file (*.ins). The PEST program INCHEK is executed to check the 'ins'-file(s). In case you remove or add replicate sets, you need to modify example.bat such that 'ins'-file(s) are checked by the INCHEK program.

3. If the optimisation is not successful, you can try re-running PEARLNEQ with different initial guesses of MasIni, DT50Ref, FacSorNeqEql, KomEql and CofRatDes.

The optimisation with PEST varies the values of the parameters within a range specified in the PEST control.pst file. This file contains default ranges as specified by the PEARLMK program. If you would like to modify the range, please open the.pst file during the first pause in the execution with the.bat file (see an example pst file in Figure 3 ). 


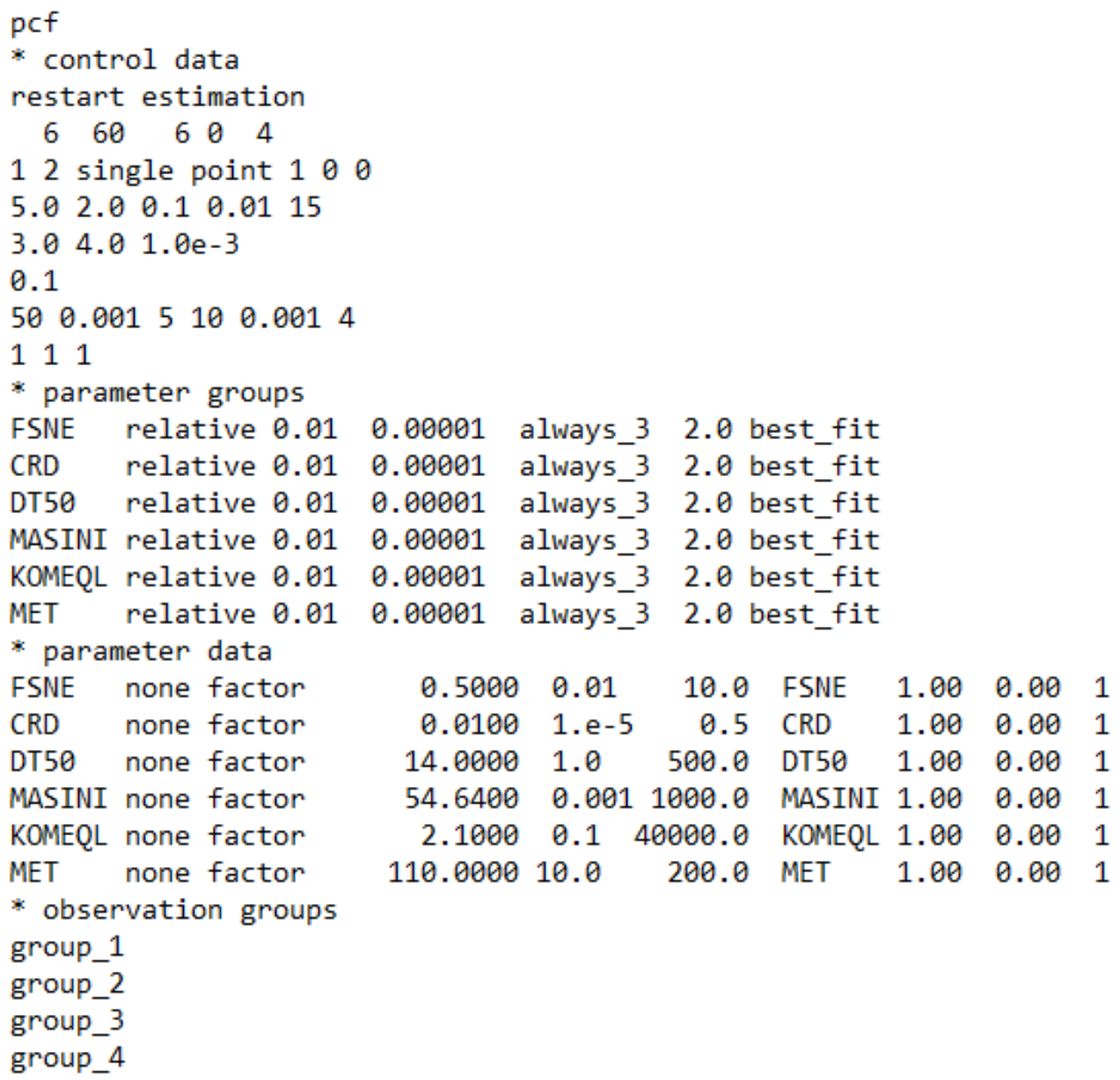

Figure 3 First part of an example pst file showing the ranges of the fitting parameters in the section 'parameter data'. The minima and maxima are given in the fifth and sixth column (e.g. 0.01 and 10.0 for FSNE). 



\title{
9 Assessment of confidence intervals of parameters by bootstrapping
}

\author{
Introduction \\ As described above, PEARLNEQ uses PEST for estimating the long-term sorption parameters (i.e. the \\ desorption rate coefficient $k_{d}$ and the factor for describing the ratio between the equilibrium and non- \\ equilibrium Freundlich coefficients $f_{N E}$ ). PEST is based on the Levenberg-Marquardt algorithm; it \\ provides best-fit values and $95 \%$ confidence intervals of the fitted parameters. Intervals of $95 \%$ \\ confidence can be used to calculate the relative standard error (RSE) which is recommended as a \\ criterion for parameter acceptance by EFSA (2018). However, in the output file containing these \\ intervals, PEST gives a warning that these intervals may be inaccurate because they are calculated on \\ the basis of a linearity assumption which may be invalid (Doherty, 2005). So, it is no surprise that the \\ $95 \%$ confidence limits from PEST sometimes are indeed inaccurate (ter Horst et al., 2013). \\ Uncertainty in model parameters may be important for regulatory decision-making. For example, \\ groundwater scenario calculations are commonly based on averages of sorption parameters derived \\ from different soils. So, in case of large differences between parameter uncertainties derived from \\ different studies, it may be advisable to give values with a large uncertainty less weight than \\ parameters with a small uncertainty (or to discard values with a large uncertainty). However, a \\ prerequisite is then that the uncertainties are assessed adequately. Thus, we decided to work on \\ improving the uncertainty assessment of $k_{d}$ and $f_{N E}$.
}

Ter Horst et al. (2013) analysed the effect of system parameters on the expected error in the longterm sorption parameters and found that the error in these parameters is mostly less than $25 \%$ if the $\mathrm{CV}$ of the parameter derived from PEST is lower than about $20 \%$. This was based on a fixed experimental design and on simulated errors derived from one source (a set of adsorption experiments with one pesticide by co-authors). However, assuming an acceptable error of $25 \%$ is an arbitrary choice, and it seems useful to develop a more generic procedure for estimating the confidence interval more accurately. So, we take a different approach: we start from the dataset under consideration and attempt to improve the estimation procedure for the confidence interval of the parameters.

We started with assessing the uncertainty by MCMC (Monte-Carlo Markov Chain) using the MetropolisHastings algorithm for stepping through the parameter space. However, this was not successful because the autocorrelation in the chain of draws of $k_{d}$ or $f_{N E}$ remained too large; this is possibly caused by the fact that PEARLNEQ fits 5-6 parameters simultaneously. An alternative is to use parametric bootstrapping (Davison \& Hinkley, 1997). This bootstrapping has the disadvantage that the computation time is about one order of magnitude longer. However, it is more robust, as it does not have such an autocorrelation problem. For these reasons, we decided to develop a parametric bootstrapping procedure.

Note that the bootstrapping method was not considered in the 2021 version of the Aged Sorption guidance (EC, 2021) and should therefore not be used for refining the RSE value in the context of the regulatory guidance for aged sorption.

\section{Procedure of parametric bootstrapping procedure}

The bootstrapping procedure works as follows:

- The model is fitted to the dataset by using PEST

- The error in the measurements is estimated from the residuals of the fit

- A large number of datasets (e.g. 1000) is generated based on the best-fit values of the parameters and based on the estimated errors assuming that these are normally distributed

- These new datasets are fitted with PEST and confidence intervals are estimated from the distribution of the fitted parameter values 
So the first step (after fitting the data to the model) is to estimate the error in the measurements. We developed this bootstrap procedure with the limitation of assuming that each measurement is equally important in the fitting procedure, i.e. using the option 'inverse'. As described before, the option 'inverse' gave best results in a few tests and is considered the standard for studies on long-term sorption kinetics (EFSA, 2018, p.16).

As described before in Chapter 5, the option 'inverse' is consistent with the concept of relative errors. So, we assume that $M_{p}$ and $C_{L}$ have normally distributed relative errors. The use of relative errors means that the errors can be expressed in terms of the coefficient of variation (CV). So, we need to estimate $C V s$ of $c_{L}$ and $M_{p}$ from the fit by PEST to the dataset. The $C V$ of $M_{p}, C V_{M}(-)$, was estimated by

$C V_{M}=\sqrt{\frac{\sum\left(\frac{M_{p, m}-M_{p, f}}{M_{p, f}}\right)^{2}}{n-p}}$

where $M_{p, m}$ is the measured mass $(\mu \mathrm{g}), M_{p, f}$ is the fitted mass $(\mu \mathrm{g}), n$ is the number of measurements and $p$ is the number of fitting parameters. The same approach was used for the $C V$ of $c_{L}$. There are five or six fitting parameters (six if data at different temperatures are available). However, we have two types of measurements $\left(c_{L}\right.$ and $M_{p}$ ) that are fitted simultaneously. It therefore seems appropriate to divide the numbers of parameters between these two types, so, using $p=2.5$ or $p=3$ for each.

We checked the use of $p=2.5$ by generating 1000 datasets for a pesticide-soil incubation system with $k_{d}=0.026 \mathrm{~d}^{-1}, f_{N E}=0.64, \operatorname{DegT5O_{EQ}}=24 \mathrm{~d}, N=0.9$, and $K_{F}=2.8 \mathrm{~L} / \mathrm{kg}$. Each dataset consisted of duplicate values of $M_{p}$ and $c_{L}$ for nine times $\left(0,15,30, \ldots, 105\right.$ and 120 days). The values of $M_{p}$ and $c_{L}$ were generated assuming normally distributed errors of $6 \%$ and $3 \%$, respectively. The 1000 datasets were fitted with PEARLNEQ/PEST, and $C V s$ of $M_{p}$ and $C_{L}$ were derived from the differences between the generated and fitted values using the above procedure (using $p=2.5$ as only data at one temperature were used). The average $C V s$ of $M_{p}$ and $c_{L}$ were found to be $6.06 \%$ and $2.98 \%$, respectively, so, very close to the true values. Thus the estimation procedure for the $C V S$ of $M_{p}$ and $c_{L}$ generated on average correct CVs (using $p=5$ instead of $p=2.5$ gave average CVs of $6.61 \%$ and $3.25 \%$, so, using $p=5$ is clearly not correct).

However, the standard deviations of the 1000 generated $C V s$ of $M_{p}$ and $C_{L}$ using $p=2.5$ were found to be $1.10 \%$ and $0.54 \%$, respectively. This indicates that there is some uncertainty when estimating a $C V$ from a single dataset (i.e. the situation in practice) that consists of duplicate values for nine times. We tested this further by generating 1000 datasets consisting each of 18 values randomly drawn from a normal distribution with a mean of 1.0 and a $C V$ of $6 \%$ (i.e. the same $C V$ as $M_{p}$ ). Calculating back the CVs of the sample population of 18 values gave a mean CV of $5.93 \%$ with a standard deviation of $1.03 \%$. This $1.03 \%$ is close to the $1.10 \%$ obtained for $M_{p}$, so, the uncertainty in the estimated CVs is probably just a consequence of having only 18 datapoints.

The next step is to generate a large number of datasets using these estimated CVs and to fit these with PEST. The last step is then to estimate the $95^{\text {th }}$ confidence interval from the statistical populations of the fitted $k_{d}$ and $f_{N E}$ values. This was done using

$P_{i}=\frac{i-\frac{1}{2}}{B}$

where $i$ is the rank number of a sorted array of the parameter values, $P_{i}$ is the percentile corresponding with the parameter value of rank number $i$ and $B$ is the total number of values of the statistical population (i.e. the number of datasets generated). This generates a large number of pairs of percentiles and parameter values from which the $95^{\text {th }}$ confidence interval was estimated by linear interpolation. Note that the bootstrapping procedure described here aims at improving the uncertainty assessment of $k_{d}$ and $f_{N E}$. The confidence interval of all other parameters optimised should be taken from the PEST output. 
We tested this procedure in a series of example calculations (see Appendix 4). A series of calculations for datasets artificially generated by assuming normally distributed relative errors showed that bootstrapping confidence intervals were usually very close to those of PEST for $k_{d}$ whereas the widths from bootstrapping were mostly smaller for $f_{N E}$. If the widths were small, also the widths for $f_{N E}$ from bootstrapping and PEST were close to each other (as was to be expected and thus can be seen as a check of the bootstrapping procedure). Although based on a limited number of cases, Appendix 4 seems to indicate that PEST confidence intervals for the aged sorption fitting procedure are reasonably accurate, especially for $k_{d}$. So the user should not expect a spectacular lowering of widths of confidence intervals by applying bootstrapping. Given also the comparatively long computation time, the use of bootstrapping seems only advisable if the widths of the confidence intervals play a critical role.

\section{Instructions for the bootstrapping procedure}

The necessary files for the bootstrap procedure are in the subdirectory 'bootstrapping'. The procedure requires that you have obtained a satisfactory fit of the data by PEARLNEQ/PEST based on an input file called source. mkn and that the results of the fit are available in the corresponding PEST output file source.rec. The subdirectory contains as an example source.mkn and source.rec files used for run $\mathrm{nr} 9$ of the example calculations described in Appendix 4. Note, that if you have used a different name during the optimisation setup (e.g. example.mkn), you have to rename the *.mkn and *.rec files to source.mkn and source.rec.

For the bootstrapping procedure to work, the file source.mkn must fulfil the following requirements:

- The Observations table should be the last part of the file

- There should be no empty lines in the file below the last line (i.e. the line with the 'end_table' statement which closes the Observations table).

So, copy your source.mkn and source.rec files to the 'bootstrapping subdirectory', go to this subdirectory and proceed as follows:

1. Specify the number of bootstrap datasets $(B)$ to be generated in the file nr_of_datasets.txt.

2. Generate these $B$ datasets by running generate_data.bat resulting in $B$ ' $m k^{\prime} n^{\prime}$-files. The initial guesses for the parameters are automatically set to the optimised values from the provided source.rec file.

3. Running generate_data.bat also gives a file source_output.txt with a listing of all differences between measured and fitted values together with the calculated standard deviations of the relative differences of $M_{p}$ and $c_{L}$ that were used to generate the datasets.

4. Furthermore this generates a file run_pearlneq.bat which should be run to fit these datasets with PEST; this results in $B$ 'rec'-files.

After the fitting of the datasets has been completed, this 'bat'-file calls the file cleanup.bat which removes PEST output files other than the 'rec'-file (besides this file, PEST generates some 20 other output files for each fit of a dataset).

5. Postprocess these $B$ 'rec'-files by running postprocess.bat which will generate an output file bootstrap_output.txt containing the bootstrapping results.

The output file contains (1) a list of all $B$ fitted parameter values of $k_{d}$ and $f_{N E}(2)$ the cumulative frequency distribution of $k_{d}$ and $f_{N E}$ and (3) the derived $95 \%$ confidence intervals of these parameters and their median using increasing numbers of datasets. An example of the last item is shown below.

Factor for describing the ratio between the equilibrium and non-equilibrium Freundlich coefficients (-)

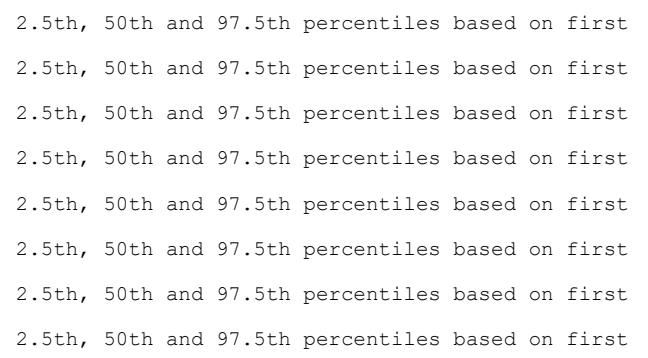

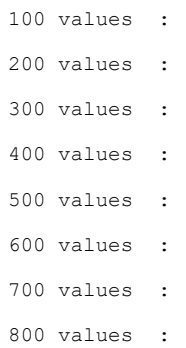

0.248

0.267

0.258

0.267

0.258

0.263

0.265

0.267

$\begin{array}{ll}0.455 & 0.706 \\ 0.443 & 0.762 \\ 0.444 & 0.790 \\ 0.444 & 0.795 \\ 0.445 & 0.790 \\ 0.444 & 0.789 \\ 0.445 & 0.788 \\ 0.442 & 0.786\end{array}$


Thus the user can check whether the number of datasets chosen was sufficiently large for obtaining an accurate $95 \%$ confidence interval.

The generation of the bootstrapping datasets is a random process which requires a seed value. This is automatically generated based on the clock time of the computer (with echo to the file seed.txt) and thus will differ between different generation procedures. In case you want for some reason the same seed, then provide a file prescribed seed.txt which contains as the only information this seed value; the value must be a negative integer lower than -10000 , so e.g. -12345 . 


\section{Literature}

Beltman W.H.J., Boesten J.J.T.I., van der Zee S.E.A.T.M. (2008). Spatial moment analysis of transport of nonlinearly adsorbing pesticides using analytical approximations. Water Resources Research 44, W05417, doi:10.1029/2007WR006436

Boesten J.J.T.I. \& L.J.T. van der Pas (2000). Movement of water, bromide and the pesticides ethoprophos and bentazone in a sandy soil: the Vredepeel data set. Agricultural Water Management 44: 21-42.

Boesten J.J.T.I. \& A.M.A. van der Linden (2001) Effect of long-term sorption kinetics on leaching as calculated with the PEARL model for FOCUS scenarios. BCPC Symposium Proceedings No. 78: Pesticide behaviour in soils and water, p. 27-32.

Boesten J.J.T.I. (2017). Effects of aged sorption on pesticide leaching to groundwater simulated with PEARL. Science of the Total Environment 576: 498-507. dx.doi.org/10.1016/j.scitotenv.2016.10.099.

Davison A.C., Hinkley D.V. (1997). Bootstrap methods and their application. Camb. Ser. Stat. Probab. Math. Vol. 1. Cambridge University Press.

Doherty J. (2005). PEST: model independent parameter estimation - User manual $5^{\text {th }}$ edition. $336 \mathrm{pp}$.

EC (2021). Guidance on how aged sorption studies for pesticides should be conducted, analysed and used in regulatory assessments. SANTE/12586/2020 - REV 026 January 2021.

EFSA (2018). Scientific Opinion about the Guidance of the Chemical Regulation Directorate (UK) on how aged sorption studies for pesticides should be conducted, analysed and used in regulatory assessments. EFSA Journal 2018;16(8):5382, 86 pp. https://doi.org/10.2903/j.efsa.2018.5382 ISSN: $1831-4732$.

FOCUS (2006). Guidance document on estimating persistence and degradation kinetics from environmental fate studies on pesticides in EU registration. EC Document Sanco/10058/2005 version 2.0, European Commission, Brussels, 434 pp. (Available at http://viso.ei.jrc.it/focus.)

Leistra, M., A.M.A. van der Linden, J.J.T.I. Boesten, A. Tiktak, F. van den Berg (2001). PEARL model for pesticide behaviour and emissions in soil-plant systems: description of the processes in FOCUS PEARL version 1.1.1. Alterra Report 013, Alterra, Wageningen. RIVM Report 711401009; RIVM Bilthoven.

Ter Horst M.M.S, Boesten J.J.T.I., van Beinum W., Beulke S. (2013). Acceptability of inverselymodelled parameters for non-equilibrium sorption of pesticides in soil. Environmental Modelling \& Software 46: 260-270.

Van den Berg F., Tiktak A., Boesten J.J.T.I., van der Linden A.M.A. (2016). PEARL model for pesticide behaviour and emissions in soil-plant systems; Description of processes. WOt-technical report 61, The Statutory Research Tasks Unit for Nature \& the Environment, Wageningen, the Netherlands, $134 \mathrm{pp}$. 



\section{Justification}

WOt-technical report: 200

BAPS project number: WOT-04-008-024

This manual describes an update of the manual of the PEARLNEQ v. 5 software tool. The manual has been prepared to assist the user with the application of the new version of PEARLNEQ, i.e. version 6, which has been developed to keep this tool in line with new scientific developments.

The authors thank Sabine Beulke, Wendy van Beinum of Enviresearch and Anton Poot and Chen Yi from Ctgb for reviewing the draft version of the manual for PEARLNEQ v.6. The reviewer's comments have been used by the authors to make further improvements to this manual.

This project belongs to the WOT theme 'Agromilieu' with theme leader Erwin van Boekel (WOT Natuur \& Milieu). The project is funded by the Ministry of Agriculture, Nature and Food Quality (project number WOT-04-008-024) with contact person Eelco Riemens.

Akkoord Extern contactpersoon

functie: Senior beleidsmedewerker gewasbescherming

naam: $\quad$ Eelco Riemens

datum: 25 mei 2021

Akkoord Intern contactpersoon

naam: $\quad$ Erwin van Boekel

datum: 28 mei 2021 



\section{Annex 1 Example input file}

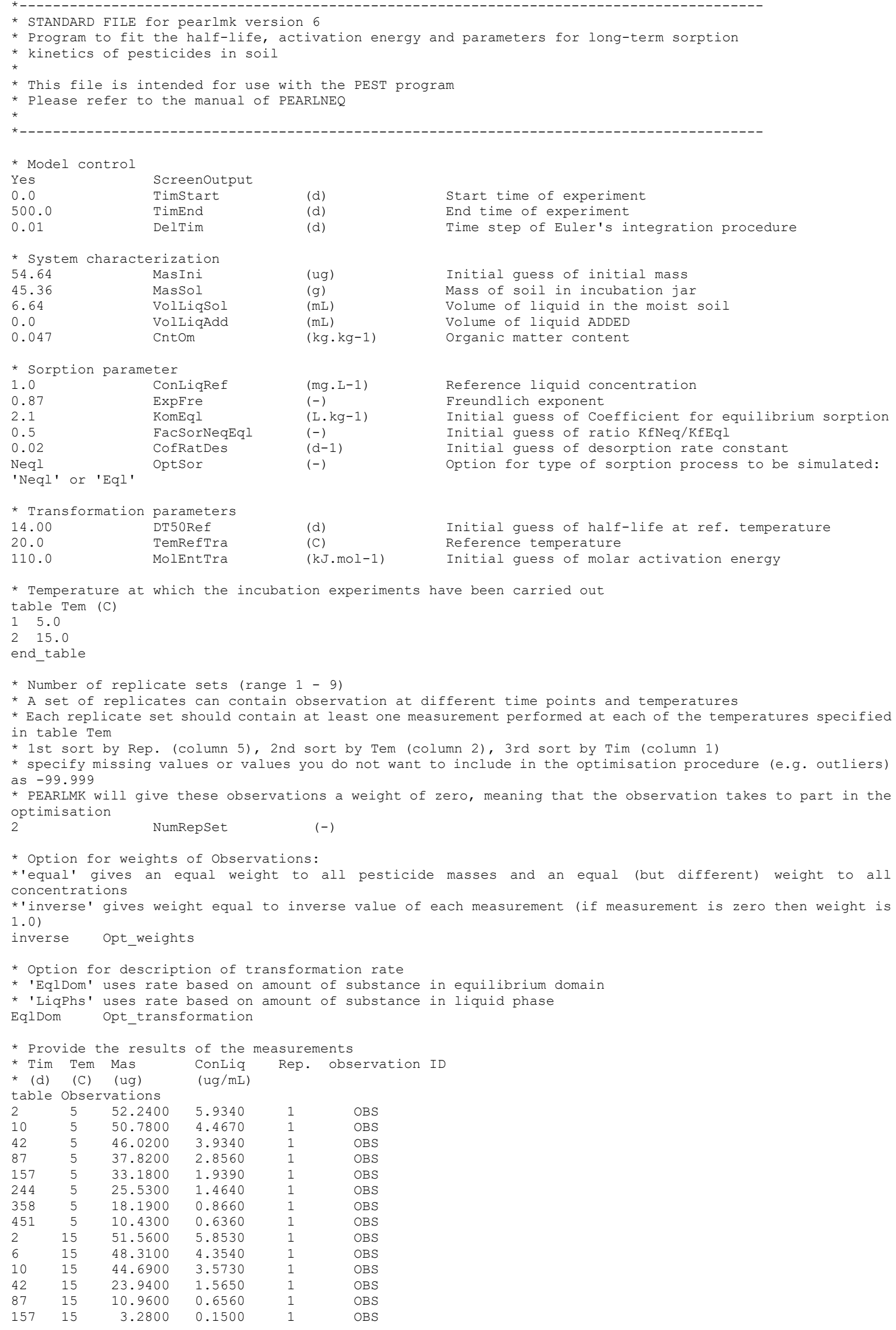




$\begin{array}{lrrrrr}244 & 15 & 1.4600 & 0.0310 & 1 & \text { OBS } \\ 2 & 5 & 51.0200 & 5.5230 & 2 & \text { OBS } \\ 10 & 5 & 50.4000 & 5.6450 & 2 & \text { OBS } \\ 42 & 5 & -99.9999 & 3.3930 & 2 & \text { OBS } \\ 87 & 5 & 39.4000 & 3.0080 & 2 & \text { OBS } \\ 157 & 5 & 32.4500 & 1.9170 & 2 & \text { OBS } \\ 244 & 5 & 26.2100 & 1.4660 & 2 & \text { OBS } \\ 358 & 5 & 22.4400 & 0.8980 & 2 & \text { OBS } \\ 451 & 5 & 8.4200 & 0.5670 & 2 & \text { OBS } \\ 2 & 15 & 51.1000 & 5.9380 & 2 & \text { OBS } \\ 6 & 15 & 46.4800 & 4.5310 & 2 & \text { OBS } \\ 10 & 15 & 54.4400 & 4.3290 & 2 & \text { OBS } \\ 42 & 15 & 22.3400 & 1.7290 & 2 & \text { OBS } \\ 87 & 15 & 10.8300 & 0.6860 & 2 & \text { OBS } \\ 157 & 15 & 2.9900 & 0.1550 & 2 & \text { OBS } \\ 244 & 15 & 1.4200 & 0.0300 & 2 & \text { OBS } \\ \text { end_table } & & & & \end{array}$




\section{Annex 2 Results of the default example}

Results (taken from last section of REC-file)

These are the results of the default example, provided with the package.

OPTIMISATION RESULTS

$\begin{array}{llll}\text { Parameters }----> & & \\ \text { Parameter } & \text { Estimated } & \text { 95\% percent } & \\ & \text { value } & \text { lower limit } & \text { upper limit } \\ \text { fsne } & 0.396764 & 0.260668 & 0.532859 \\ \text { crd } & 5.660101 \mathrm{E}-03 & 2.669861 \mathrm{E}-03 & 8.650341 \mathrm{E}-03 \\ \text { dt50 } & 15.2563 & 14.1249 & 16.3877 \\ \text { masini } & 56.6135 & 53.5068 & 59.7203 \\ \text { komeql } & 2.79245 & 2.34462 & 3.24027 \\ \text { met } & 105.646 & 101.796 & 109.496\end{array}$

Note: confidence limits provide only an indication of parameter uncertainty. They rely on a linearity assumption which may not extend as far in parameter space as the confidence limits themselves - see PEST manual.

See file example.sen for parameter sensitivities.

Observations ----->

\begin{tabular}{|c|c|c|c|c|c|}
\hline Observation & $\begin{array}{l}\text { Measured } \\
\text { value }\end{array}$ & $\begin{array}{l}\text { Calculated } \\
\text { value }\end{array}$ & Residual & Weight & Group \\
\hline ○1 & 52.2400 & 56.1193 & -3.87932 & $1.9142 \mathrm{E}-02$ & group_1 \\
\hline ०2 & 5.93400 & 4.87707 & 1.05693 & 0.1685 & group_1 \\
\hline ०3 & 50.7800 & 54.1942 & -3.41422 & $1.9693 \mathrm{E}-02$ & group_1 \\
\hline$\circ 4$ & 4.46700 & 4.66290 & -0.195900 & 0.2239 & group_1 \\
\hline ०5 & 46.0200 & 47.2533 & -1.23326 & $2.1730 \mathrm{E}-02$ & group_1 \\
\hline 06 & 3.93400 & 3.90901 & $2.498741 \mathrm{E}-02$ & 0.2542 & group_1 \\
\hline 07 & 37.8200 & 39.2265 & -1.40653 & $2.6441 \mathrm{E}-02$ & group_1 \\
\hline ०8 & 2.85600 & 3.07750 & -0.221498 & 0.3501 & group_1 \\
\hline 09 & 33.1800 & 29.7653 & 3.41472 & $3.0139 \mathrm{E}-02$ & group_1 \\
\hline 010 & 1.93900 & 2.16413 & -0.225132 & 0.5157 & group_1 \\
\hline o11 & 25.5300 & 21.5310 & 3.99896 & $3.9170 \mathrm{E}-02$ & group_1 \\
\hline o12 & 1.46400 & 1.44149 & $2.250611 \mathrm{E}-02$ & 0.6831 & group_1 \\
\hline 013 & 18.1900 & 14.4324 & 3.75758 & $5.4975 E-02$ & group_1 \\
\hline 014 & 0.866000 & 0.884725 & $-1.872510 \mathrm{E}-02$ & 1.155 & group_1 \\
\hline o15 & 10.4300 & 10.5670 & -0.137019 & $9.5877 \mathrm{E}-02$ & group_1 \\
\hline 016 & 0.636000 & 0.611510 & $2.448954 \mathrm{E}-02$ & 1.572 & group_1 \\
\hline 017 & 51.5600 & 54.2417 & -2.68173 & $1.9395 \mathrm{E}-02$ & group_2 \\
\hline ०18 & 5.85300 & 4.70441 & 1.14859 & 0.1709 & group_2 \\
\hline o19 & 48.3100 & 49.8048 & -1.49476 & $2.0700 \mathrm{E}-02$ & group_2 \\
\hline 020 & 4.35400 & 4.27968 & $7.432244 \mathrm{E}-02$ & 0.2297 & group_2 \\
\hline 21 & 44.6900 & 45.7471 & -1.05710 & $2.2376 \mathrm{E}-02$ & grou \\
\hline
\end{tabular}




\begin{tabular}{|c|c|c|c|c|c|}
\hline 022 & 3.57300 & 3.89342 & -0.320422 & 0.2799 & group_2 \\
\hline 023 & 23.9400 & 23.5524 & 0.387621 & $4.1771 \mathrm{E}-02$ & group_2 \\
\hline 024 & 1.56500 & 1.83091 & -0.265914 & 0.6390 & group_2 \\
\hline 025 & 10.9600 & 9.93362 & 1.02638 & $9.1241 \mathrm{E}-02$ & group_2 \\
\hline 026 & 0.656000 & 0.643754 & $1.224635 \mathrm{E}-02$ & 1.524 & group_2 \\
\hline 027 & 3.28000 & 3.36264 & $-8.264049 \mathrm{E}-02$ & 0.3049 & group_2 \\
\hline 028 & 0.150000 & 0.140282 & $9.718440 \mathrm{E}-03$ & 6.667 & group_2 \\
\hline 029 & 1.46000 & 1.41841 & $4.159341 \mathrm{E}-02$ & 0.6849 & group_2 \\
\hline 030 & $3.100000 \mathrm{E}-02$ & $3.173109 \mathrm{E}-02$ & $-7.310900 \mathrm{E}-04$ & 32.26 & group_2 \\
\hline 031 & 51.0200 & 56.1193 & -5.09932 & $1.9600 \mathrm{E}-02$ & group_3 \\
\hline ०32 & 5.52300 & 4.87707 & 0.645931 & 0.1811 & group_3 \\
\hline 033 & 50.4000 & 54.1942 & -3.79422 & $1.9841 \mathrm{E}-02$ & group_3 \\
\hline 034 & 5.64500 & 4.66290 & 0.982100 & 0.1771 & group_3 \\
\hline ०35 & -99.9999 & 47.2533 & -147.253 & 0.000 & group_3 \\
\hline 036 & 3.39300 & 3.90901 & -0.516013 & 0.2947 & group_3 \\
\hline 037 & 39.4000 & 39.2265 & 0.173472 & $2.5381 \mathrm{E}-02$ & group_3 \\
\hline 038 & 3.00800 & 3.07750 & $-6.949845 E-02$ & 0.3324 & group_3 \\
\hline 039 & 32.4500 & 29.7653 & 2.68472 & $3.0817 \mathrm{E}-02$ & group_3 \\
\hline$\circ 40$ & 1.91700 & 2.16413 & -0.247132 & 0.5216 & group_3 \\
\hline 041 & 26.2100 & 21.5310 & 4.67896 & $3.8153 \mathrm{E}-02$ & group_3 \\
\hline$\circ 42$ & 1.46600 & 1.44149 & $2.450611 \mathrm{E}-02$ & 0.6821 & group_3 \\
\hline 043 & 22.4400 & 14.4324 & 8.00758 & $4.4563 E-02$ & group_3 \\
\hline ०44 & 0.898000 & 0.884725 & $1.327490 \mathrm{E}-02$ & 1.114 & group_3 \\
\hline$\circ 45$ & 8.42000 & 10.5670 & -2.14702 & 0.1188 & group_3 \\
\hline 046 & 0.567000 & 0.611510 & $-4.451046 \mathrm{E}-02$ & 1.764 & group_3 \\
\hline$\circ 47$ & 51.1000 & 54.2417 & -3.14173 & $1.9569 \mathrm{E}-02$ & group_4 \\
\hline 048 & 5.93800 & 4.70441 & 1.23359 & 0.1684 & group_4 \\
\hline 049 & 46.4800 & 49.8048 & -3.32476 & $2.1515 \mathrm{E}-02$ & group_4 \\
\hline$\circ 50$ & 4.53100 & 4.27968 & 0.251322 & 0.2207 & group_4 \\
\hline ०51 & 54.4400 & 45.7471 & 8.69290 & $1.8369 \mathrm{E}-02$ & group_4 \\
\hline 052 & 4.32900 & 3.89342 & 0.435578 & 0.2310 & group_4 \\
\hline 053 & 22.3400 & 23.5524 & -1.21238 & $4.4763 E-02$ & group_4 \\
\hline ०54 & 1.72900 & 1.83091 & -0.101914 & 0.5784 & group_4 \\
\hline ०55 & 10.8300 & 9.93362 & 0.896377 & $9.2336 \mathrm{E}-02$ & group_4 \\
\hline ०56 & 0.686000 & 0.643754 & $4.224635 \mathrm{E}-02$ & 1.458 & group_4 \\
\hline 057 & 2.99000 & 3.36264 & -0.372640 & 0.3344 & group_4 \\
\hline 058 & 0.155000 & 0.140282 & $1.471844 \mathrm{E}-02$ & 6.452 & group_4 \\
\hline 059 & 1.42000 & 1.41841 & $1.593410 \mathrm{E}-03$ & 0.7042 & group_4 \\
\hline 060 & $3.000000 \mathrm{E}-02$ & $3.173109 \mathrm{E}-02$ & $-1.731090 \mathrm{E}-03$ & 33.33 & group_4 \\
\hline
\end{tabular}


Explanation of the observations and groups in the 'Observations' table in the PEST *.rec output file

Group:

- group_1 - contains all observations of Mas $^{1}$ and ConLiq ${ }^{2}$ belonging to replicate set 1 and the first temperature at which the incubation experiments have been carried out ( $5 \mathrm{C}$ in the example)

- group_2 - contains all observations of Mas $^{1}$ and ConLiq ${ }^{2}$ belonging to replicate set 1 and the second temperature at which the incubation experiments have been carried out ( $15 \mathrm{C}$ in the example)

- group_3 - contains all observations of Mas $^{1}$ and ConLiq ${ }^{2}$ belonging to replicate set 2 and the first temperature at which the incubation experiments have been carried out ( $5 \mathrm{C}$ in the example)

- group_4 - contains all observations of Mas $^{1}$ and ConLiq ${ }^{2}$ belonging to replicate set 2 and the second temperature at which the incubation experiments have been carried out (15 $\mathrm{C}$ in the example)

Observations:

The observations with the odd numbers (01, 03 etc.) are masses and those with the even numbers ( 02,04 etc.) are concentrations in the liquid phase.

1 Mas: the total mass of pesticide in the system $(\mu \mathrm{g})$

${ }^{2}$ ConLiq: the concentration of pesticide $\left(\mu \mathrm{g} \mathrm{mL}^{-1}\right)$ measured in the pore water of moist soil (then VolLiqAdd $=0$ ) or in the water. phase after a desorption experiment (in which case VolLiqAdd is not zero). 


\section{Annex 3 Comparison between an analytical solution and PEARLNEQ}

In this appendix an analytical solution for the remaining mass of pesticide is compared with the PEARLNEQ solution. The system properties were:

- Mass of dry soil (MasSol) (g)

- Volume of water in moist soil (VolLiqsol) $(\mathrm{mL})$

- Volume of water added (VolLiqAdd ( $\mathrm{mL}$ )

- Initial mass of pesticide (MasIni) (ug)

- Reference concentration (ConLiqRef) (ug.mL-1)

- Equilibrium sorption coefficient (CofFreEql) (mL.g-1)

- Non-equili. sorption coefficient (CofFreNeq) (mL.g-1)

- Freundlich exponent (ExFre) (-)

- Desorption rate coefficient (CofRatDes) (d-1)

- Half-life transformation (DT50Ref) (d)

- Reference temperature (TemRefTra) (K)
1.0000

0.2000

0.0000

10.0000

1.0000

1.0000

0.5000

1.0000

0.0100

1.0000

293.1500

The transformation rate concept of Eqn 5-A was used.

The analytical solution was taken from Appendix 4 of FOCUS (2006).

The figure shows that the PEARLNEQ solution coincides very well with the analytical solution.

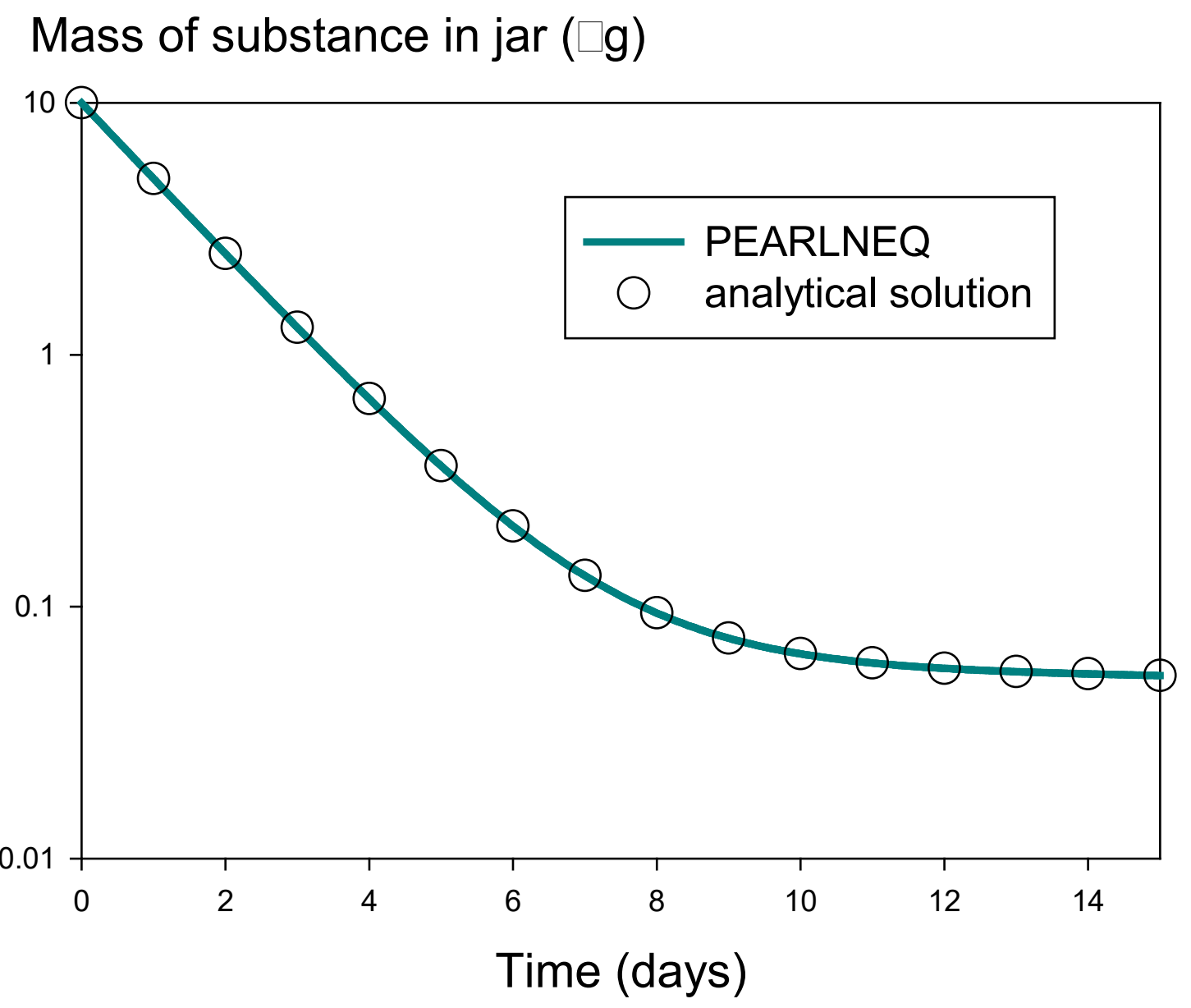

Comparison between the analytical solution and the PEARLNEQ solution 


\section{Annex 4 Example calculations of bootstrapping confidence intervals}

A series of example calculations was carried out to illustrate the bootstrapping application. The procedure was as follows:

- a single dataset was generated assuming normally distributed errors in remaining mass $\left(M_{p}\right)$ and concentration in liquid phase $\left(C_{L}\right)$ with coefficients of variation $(\mathrm{CVs})$ of $6 \%$ and $3 \%$, respectively; this dataset is called the 'source dataset'; we expect these $6 \%$ and $3 \%$ to be realistic (e.g. ter Horst et al., 2013, found $7 \%$ and $4 \%$ for experiments with four soils and one pesticide)

- this dataset was fitted with PEST and from the differences between fitted and measured values the CVs of $M_{p}$ and $c_{L}$ were estimated using Eqn 12 as described in Chapter 9

- based on these fitted $M_{p}$ and $C_{L}$ values and their estimated CVs, a large number (999) of datasets (further called 'bootstrap data sets') were generated assuming normally distributed errors in $M_{p}$ and $C_{L}$ and these were all fitted with PEST

- 2.5 and 97.5 percentiles of $k_{d}$ and $f_{N E}$ estimated by PEST for the source dataset were compared to the 2.5 and 97.5 percentiles of $k_{d}$ and $f_{N E}$ estimated from the best-fit values derived from the bootstrap datasets)

The source and bootstrap datasets consisted of duplicate values of $M_{p}$ and $c_{L}$ for nine times $(0,15,30$, $45,60,75,90,105$ and 120 days). The Freundlich exponent was fixed to 0.9. Calculations were made for three combinations of $k_{d}$ and $f_{N E}$ based on an earlier analysis of $k_{d}$ and $f_{N E}$ data (Boesten, 2017), representing small, medium and large effects of aged sorption:

\begin{tabular}{lll} 
Effect of aged sorption & $k_{d}\left(\mathrm{~d}^{-1}\right)$ & $f_{N E}(-)$ \\
Small & 0.032 & 0.33 \\
\hline Medium & 0.026 & 0.64 \\
\hline Large & 0.014 & 2.99 \\
\hline
\end{tabular}

Calculations were made for three combinations of $K_{F}$ and the half-life for the equilibrium part of the aged sorption system, DegT5OEQ. These combinations were selected in such a way that they would result in a FOCUS leaching concentration of about $1 \mu \mathrm{g} / \mathrm{L}$ for the FOCUS Kremsmuenster scenario based on calculations assuming no aged sorption (Boesten, 2017). This procedure was followed to ensure that the corresponding substances would require a higher-tier approach such as including aged sorption. These Kremsmuenster calculations showed that this leaching concentration was approximately found if the $K_{\text {om }}$ is equal to 1.8 times the DegT50 SFO (i.e. the DegT5O assuming single first-order kinetics). The organic matter content of the top layer in Kremsmuenster is 0.036 , which gives then $K_{F}=0.07$ DegT50 SFO. The DegT50 $_{E Q}$ can be approximated by DegT50 SFO / $\left(1+f_{N E}\right)$

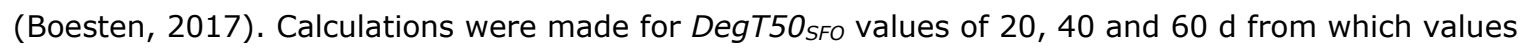
of $K_{F}$ and $D e g T 50_{E Q}$ were derived using these approximations. This resulted in the combinations of input parameters for the nine cases as shown in Table 1. 
Table 1 Pesticide properties used for example calculations based on the Kremsmuenster scenario.

\begin{tabular}{|c|c|c|c|c|c|}
\hline $\mathrm{Nr}$ & DegT50sfo (d) & $K_{F}(L / k g)$ & $k_{d}\left(d^{-1}\right)$ & $f_{N E}(-)$ & DegT50EQ (d) \\
\hline 1 & \multirow[b]{2}{*}{20} & \multirow[b]{2}{*}{1.4} & 0.032 & 0.33 & 15 \\
\hline 2 & & & 0.026 & 0.64 & 12 \\
\hline 4 & \multirow[b]{2}{*}{40} & \multirow[b]{2}{*}{2.8} & 0.032 & 0.33 & 30 \\
\hline 5 & & & 0.026 & 0.64 & 24 \\
\hline 7 & \multirow{3}{*}{60} & \multirow{3}{*}{4.2} & 0.032 & 0.33 & 45 \\
\hline 8 & & & 0.026 & 0.64 & 37 \\
\hline 9 & & & 0.014 & 2.99 & 15 \\
\hline
\end{tabular}

The results in Table 2 and Table 3 indicate that the confidence intervals based on bootstrapping were either approximately equal to those obtained from a single PEST fit or smaller. This is further illustrated by the widths of the confidence interval divided by the median parameter value (called 'relative widths') as shown in Figure 1: the relative widths of the intervals from PEST and bootstrapping were usually very close to each other for $k_{d}$ whereas the widths from bootstrapping were mostly smaller for $f_{N E}$. One would expect that the confidence intervals from PEST and bootstrapping are the same if they are small: Figure 1 shows that this is indeed the case. Table 4 gives the numbers of the relative widths of the confidence intervals for the different datasets. Combination with Table 1 shows that the relative widths decrease with increasing value of $f_{N E}$.

Table 2 Upper and lower limits of the 95\% confidence interval of the desorption rate coefficient $k_{d}$ and its median value (derived from PEST or bootstrapping) for the example calculations with pesticide properties as shown in Table 1.

\begin{tabular}{|c|c|c|c|c|c|c|}
\hline \multirow[b]{3}{*}{ Set } & \multicolumn{6}{|c|}{$k_{d}\left(d^{-1}\right) \times 10000$} \\
\hline & \multicolumn{2}{|c|}{ Lower limit } & \multicolumn{2}{|c|}{ Median } & \multicolumn{2}{|c|}{ Upper Iimit } \\
\hline & PEST & Bootstrap & PEST & Bootstrap & PEST & Bootstrap \\
\hline 2 & 227 & 229 & 247 & 248 & 268 & 268 \\
\hline 3 & 128 & 128 & 134 & 135 & 141 & 141 \\
\hline 5 & 219 & 225 & 262 & 262 & 306 & 307 \\
\hline 6 & 132 & 132 & 140 & 140 & 149 & 149 \\
\hline 7 & 178 & 210 & 294 & 294 & 410 & 429 \\
\hline 8 & 198 & 211 & 264 & 263 & 330 & 329 \\
\hline
\end{tabular}

Table 3 Upper and lower limits of the 95\% confidence interval of the desorption rate coefficient $f_{N E}$ and its median value (derived from PEST or bootstrapping) for the example calculations with pesticide properties as shown in Table 1.

\begin{tabular}{|c|c|c|c|c|c|c|}
\hline \multirow[t]{3}{*}{ Set } & \multicolumn{6}{|c|}{$f_{N E}(-) \times 1000$} \\
\hline & \multicolumn{2}{|c|}{ Lower limit } & \multicolumn{2}{|c|}{ Median } & \multicolumn{2}{|c|}{ Upper Iimit } \\
\hline & PEST & Bootstrap & PEST & Bootstrap & PEST & Bootstrap \\
\hline 1 & 301 & 319 & 348 & 349 & 395 & 380 \\
\hline 2 & 619 & 636 & 671 & 671 & 723 & 711 \\
\hline 4 & 276 & 296 & 334 & 336 & 392 & 382 \\
\hline 5 & 568 & 586 & 650 & 653 & 732 & 727 \\
\hline 6 & 2867 & 2873 & 3069 & 3069 & 3271 & 3303 \\
\hline 7 & 271 & 290 & 358 & 360 & 445 & 442 \\
\hline
\end{tabular}




\section{Width confidence interval (\%) from bootstrapping}

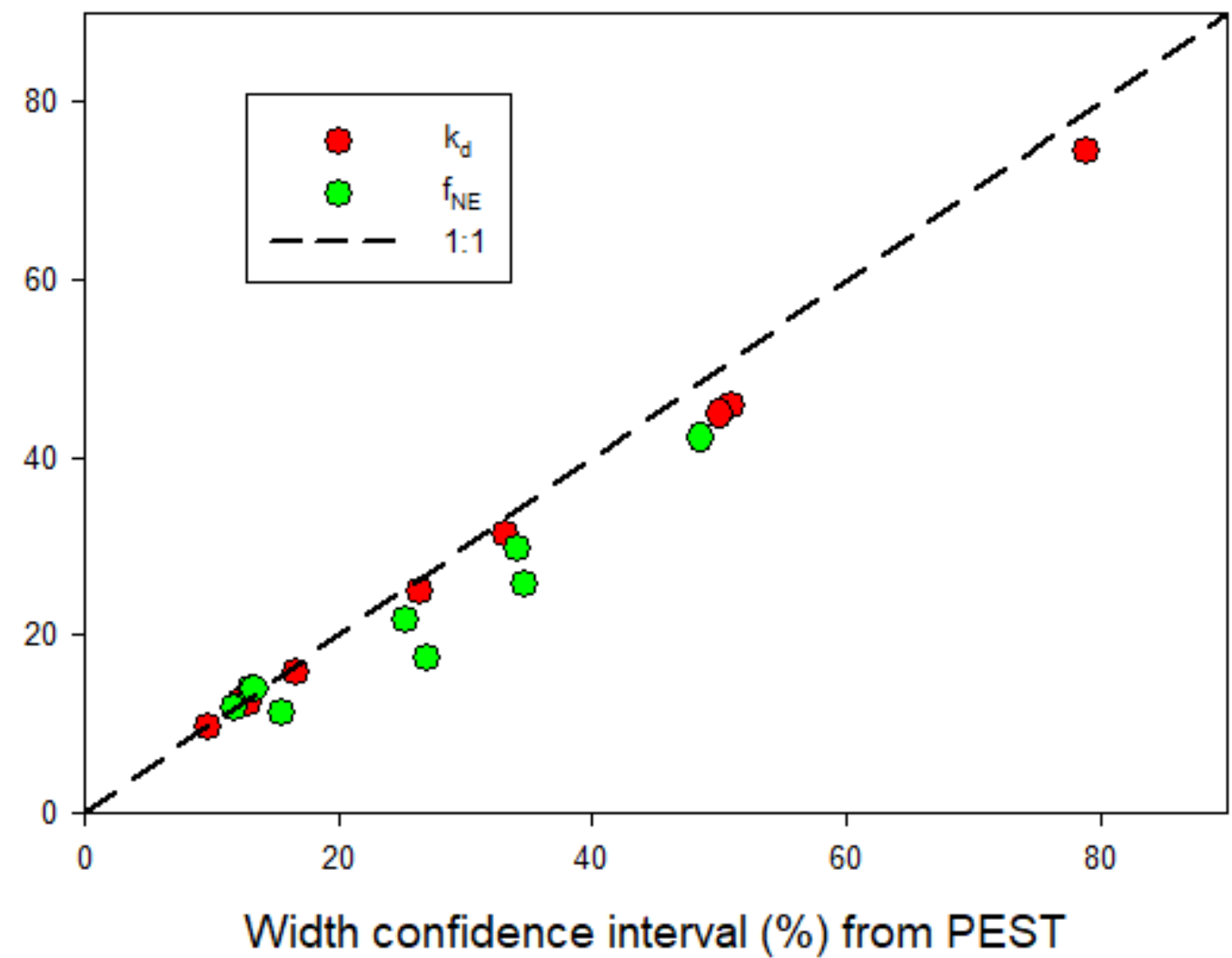

Figure 1 Relative width of the 95\% confidence interval (defined as the width of the interval expressed as a percentage of the median) as estimated with the bootstrapping procedure as a function of the corresponding width estimated with PEST from the source data set.

Table 4 Relative widths of the 95\% confidence interval of $k_{d}$ and $f_{N E}$ in percents (derived from PEST or bootstrapping) for the example calculations with pesticide properties as shown in Table 1.

\begin{tabular}{|c|c|c|c|c|}
\hline Set & \multicolumn{2}{|c|}{$\%$ for $k_{d}$} & \multicolumn{2}{|c|}{$\%$ for $f_{N E}$} \\
\hline 1 & 26.4 & 24.9 & 27.0 & 17.5 \\
\hline 2 & 16.6 & 15.8 & 15.5 & 11.2 \\
\hline 3 & 9.7 & 9.7 & 11.8 & 11.8 \\
\hline 6 & 12.1 & 12.9 & 13.2 & 14.1 \\
\hline 7 & 78.9 & 74.8 & 48.6 & 42.2 \\
\hline 8 & 50.0 & 44.9 & 34.2 & 29.2 \\
\hline 9 & 12.9 & 12.2 & 13.4 & 13.9 \\
\hline
\end{tabular}





\section{Published documents in the Technical reports series of the Statutory Research Tasks Unit for}

Nature \& the Environment.

168 Arets, E.J.M.M., J.W.H van der Kolk, G.M. Hengeveld, J.P. Lesschen, H. Kramer, P.J. Kuikman \& M.J. Schelhaas (2020). Greenhouse gas reporting of the LULUCF sector in the Netherlands. Methodological background, update 2020.

169 Van Kraalingen, D., E.L. Wipfler, F. van den Berg, W.H.J. Beltman, M.M.S. ter Horst \& J.A. te Roller (2020). User manual for FOCUSSPIN version 3.3.

170 Bos-Groenendijk, G.I., C.A.M van Swaay (2020). Habitatrichtlijnrapportage 2019: Annex B Habitatrichtlijnsoorten; Achtergronddocument.

171 Janssen, J.A.M. (red.), R.J. Bijlsma (red.), G.H.P. Arts, M.J. Baptist, S.M. Hennekens, B. de Knegt, T. van der Meij, J.H.J. Schaminée, A.J. van Strien, S. Wijnhoven, T.J.W. Ysebaert (2020). Habitatrichtlijnrapportage 2019: Annex D Habitattypen. Achtergronddocument.

172 Van Kleunen, A., M. van Roomen, E. van Winden, M. Hornman, A. Boele, C. Kampichler, D. Zoetebier, H. Sierdsema \& C. van Turnhout (2020). Vogelrichtlijnrapportage 2013-2018 van Nederland - status en trends van soorten.

173 Glorius, S.T., A. Meijboom (2020). Ontwikkeling van de bodemdiergemeenschap in de geulen van referentiegebied Rottum; Tussenrapportage 13 jaar na sluiting (najaar 2018).

174 Kuindersma, W., D. van Doren, R. Arnouts, D.A. Kamphorst, J.G. Nuesink, E. de Wit-de Vries (2020). Realisatie Natuurnetwerk door provincies. Achtergrondstudie bij de Tweede Lerende Evaluatie Natuurpact.

175 Bouwma, I.M., D.A. Kamphorst, D. van Doren, T.A. de Boer, A.E. Buijs, C.M. Goossen, J.L.M. Donders, J.Y. Frissel, S. van Broekhoven (2020). Provinciaal beleid voor maatschappelijke betrokkenheid bij natuur het beleid nader bekeken in 8 casussen. Achtergrondstudie bij de Tweede Lerende Evaluatie Natuurpact.

176 Gerritsen, A.L., H. Agricola, C. Aalbers, J. van Os (2020). Natuur en landbouw verbinden. Achtergrondstudie bij de Tweede Lerende Evaluatie Natuurpact.

177 Brouwer, F., D.J.J. Walvoort (2020). Basisregistratie Ondergrond (BRO) Actualisatie bodemkaart. Herkartering van de veengebieden aan de flanken van de Utrechtse Heuvelrug.

178 Bruggen, C. van, A. Bannink, C.M. Groenestein J.F.M. Huijsmans, L.A. Lagerwerf, H.H. Luesink, G.L. Velthof \& J. Vonk (2020). Emissies naar lucht uit de landbouw, 1990-2018; Emissies van ammoniak, stikstofoxide, lachgas, methaan, niet-methaan vluchtige organische stoffen, fijnstof en koolstofdioxide uit kalkmeststoffen - Berekeningen met het model NEMA.

179 Knegt, de B., M. Pleijte, E. de Wit-de Vries, I. Bouwma, F. Kistenkas, W. Nieuwenhuizen (2020). Samenhang Klimaatakkoord en natuurbeleid. Proces en implementatie van het Klimaatakkoord door provincies en maatschappelijke partijen en de potentiële effecten op biodiversiteitsdoelen van de Vogelen Habitatrichtlijn.

180 Mattijssen T.J.M., M. Pleijte, J. Dengerink, T. Koster, M. Visscher (2020). Indicatoren voor burgerbetrokkenheid bij natuur: een zoektocht naar nieuwe aanknopingspunten voor monitoring.

181 Kamphorst, D.A., M. Pleijte, F. Kistenkas (2020). Uitvoering van de Vogel- en Habitatrichtlijn in de praktijk: spanningen en mogelijke oplossingsrichtingen.

182 Elschot K., M.E.B. Van Puijenbroek, D.D.G. Lagendijk, J-T. Van der Wal, C. Sonneveld (2020). Lange-termijnontwikkeling van kwelders in de Waddenzee (1960-2018).

183 Koffijberg K., P. de Boer, S.C.V. Geelhoed, J. Nienhuis, K. Oosterbeek, J. Postma (2020). Broedsucces van kustbroedvogels in de Waddenzee in 2018.

184 IJsseldijk, L.L., M.J.L. Kik, L. van Schalkwijk \& A. Gröne (2020). Postmortaal onderzoek van bruinvissen (Phocoena phocoena) uit Nederlandse wateren, 2019. Biologische gegevens, gezondheidsstatus en doodsoorzaken.

185 Os, J. van, L.J.J. Jeurissen, J.C. Verkaik (2020). Rekenregels schapen en geiten voor de landbouwtelling; Verantwoording van het gebruik van het Identificatie \& Registratiesysteem.

186 Bakker, G., M. Heinen, H.P.A. Gooren, W.J.M. de Groot, P.D. Peters (2020). Hydrofysische gegevens van de bodem in de Basisregistratie Ondergrond (BRO) en het Bodemkundig Informatie Systeem (BIS); Update 2019.

187 Kuindersma, W., E. de Wit - de Vries, F.G. Boonstra, M. Pleijte, D.A. Kamphorst (2020). Het Nederlandse natuurbeleid in zijn institutionele context. Beschrijving en analyse van de interne en externe congruentie van het Nederlandse natuurbeleidsarrangement in relatie tot landbouwbeleid, waterbeleid (voor de grote rivieren) en recreatiebeleid (19752018). 
188 Kuiters, A.T., G.A. de Groot, D.R. Lammertsma, H.A.H. Jansman, J. Bovenschen (2020). Genetische monitoring van de Nederlandse otterpopulatie; Ontwikkeling van populatieomvang en genetische status 2019/2020.

189 Gerritsen, A.L., H.J. Agricola \& J. van Os (2020). Ruimtelijk-economische dynamiek van de landbouw. Rapport 1: analyses van ontwikkelingen in gewasarealen, dieraantallen, grondgebruik, grondprijzen, verdiencapaciteiten en verbredingsactiviteiten.

190 Pouwels, R., A. van Hinsberg, V. Mensing, S. van Tol \& J.Y. Frissel (2020). Achtergrondrapport referentiescenario's natuurverkenning 2050

191 Hennekens, S., J. Holtland, N. van Rooijen, W. Wamelink \& W. Ozinga (2020).

Indicatiewaarden voor voedselrijkdom van de bodem; een vergelijking tussen drie indicatiesystemen.

192 Glorius, S.T. \& A. Meijboom (2020). Ontwikkeling van enkele droogvallende mosselbanken in de Nederlandse Waddenzee; situatie 2019.

193 Glorius, S.T. \& A. Meijboom (2020). Ontwikkeling van de bodemdiergemeenschap in de geulen van referentiegebied Rottum; Tussenrapportage 14 jaar na sluiting (najaar 2019).

194 Adams, A.S. \& W.J. Remmelts (2020). Achtergronddocumentatie Vogel- en Habitatrichtlijnrapportage Annex A.

195 Van der Meij, W.M. \& G.J. Maas (2020). Kwaliteitsdocument van de Geomorfologische kaart van Nederland.

196 Buijs, A.E., D.A. Kamphorst, C.B.E.M. Aalbers (2020). Draagt maatschappelijke betrokkenheid bij aan de legitimiteit van het natuurbeleid? Inventarisatie van beleidsverwachtingen en review van literatuur.

197 Knegt, B. de, M. van der Aa, L. van Gerven, K. Hendriks, S. Koopmans, M. Lof, M. Riksen, $\mathrm{H}$. Roelofsen, S. de Vries, I. Woltjer (2020). Graadmeter Diensten van Natuur, update 2020; Vraag, aanbod, gebruik en trend van goederen en diensten uit ecosystemen in Nederland.
198 Bouwma, I.M., M.C. van Riel, J.G. Nuesink, J.A Veraart, R. Pouwels (2020). Verkenning naar de samenhang van de Vogel- en Habitatrichtlijn en de Kaderrichtlijn Water. Een analyse voor het vergroten van de synergie tussen de richtlijnen.

199 Müskens, G., M. La Haye, R. van Kats, S. Moonen \& E.A. van der Grift (2020). Ontwikkeling van de hamsterpopulatie in Limburg; Stand van zaken 2019-2020.

200 J.J.T.I. Boesten, M.M.S. ter Horst (2021). Manual for PEARLNEQ v6.

201 Arets, E.J.M.M., J.W.H van der Kolk, G.M. Hengeveld, J.P. Lesschen, H. Kramer, P.J. Kuikman \& M.J. Schelhaas (2021). Greenhouse gas reporting of the LULUCF sector in the Netherlands. Methodological background, update 2021.

202 M.E. Sanders, H.A.M Meeuwsen, H.D. Roelofsen, R.J.H.G. Henkens (2021). Voortgang natuurnetwerk en areaal beschermd natuurgebied. Technische achtergronden bij de digitale Balans van de Leefomgeving 2020.

203 Bruggen, C. van, A. Bannink, C.M. Groenestein, J.F.M. Huijsmans, L.A. Lagerwerf, H.H. Luesink, M.B.H. Ros, G.L. Velthof, J. Vonk en T. van der Zee (2021). Emissies naar lucht uit de landbouw berekend met NEMA voor 19902019.

204 IJsseldijk, L.L., van Schalkwijk, L., M.J.L. Kik \& A Gröne (2021). Postmortaal onderzoek van bruinvissen (Phocoena phocoena) uit Nederlandse wateren, 2020. Biologische gegevens, gezondheidsstatus en doodsoorzaken.

205 Kros, J., J.C.H. Voogd, J. van Os, L.J.J. Jeurissen (2021). INITIATOR Versie 5 - Status $A$; Beschrijving van de kwaliteitseisen ter verkrijging van het kwaliteitsniveau Status $A$.

206 Waenink, R., D.J. van der Hoek, B. de Knegt \& J. Schütt (2021). Aanbevelingen voor verbetering van de landelijke analyse van effect herstelmaatregelen op biodiversiteit; Verdiepende analyse in zes natuurgebieden. 



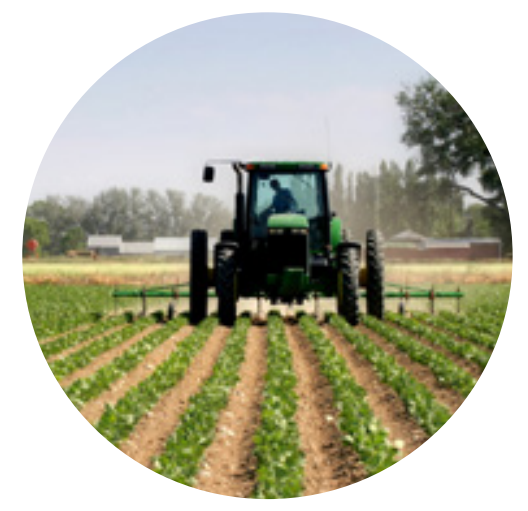

Theme Agri-Environment Wettelijke Onderzoekstaken Natuur \& Milieu

P.O. Box 47

6700 AA Wageningen

T (0317) 485471

E info.wnm@wur.nl

ISSN 2352-2739

www.wur.nl/wotnatuurenmilieu

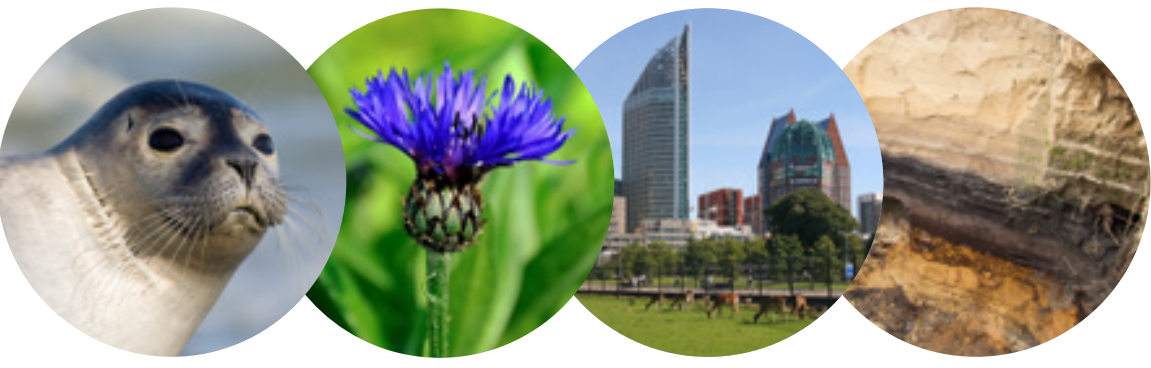

The mission of Wageningen University \& Research is "To explore the potential of nature to improve the quality of life". Under the banner Wageningen University \& Research, Wageningen University and the specialised research institutes of the Wageningen Research Foundation have joined forces in contributing to finding solutions to important questions in the domain of healthy food and living environment. With its roughly 30 branches, 6,500 employees (5,500 fte) and 12,500 students, Wageningen University \& Research is one of the leading organisations in its domain. The unique Wageningen approach lies in its integrated approach to issues and the collaboration between different disciplines.

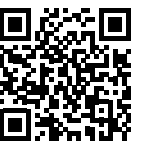

